Portland State University

PDXScholar

5-6-1977

\title{
Speech Improvement as an Aid to Language Development
}

Marilyn Gould Knauf

Portland State University

Follow this and additional works at: https://pdxscholar.library.pdx.edu/open_access_etds

Part of the Speech Pathology and Audiology Commons Let us know how access to this document benefits you.

\section{Recommended Citation}

Knauf, Marilyn Gould, "Speech Improvement as an Aid to Language Development" (1977). Dissertations and Theses. Paper 2436.

https://doi.org/10.15760/etd.2437

This Thesis is brought to you for free and open access. It has been accepted for inclusion in Dissertations and Theses by an authorized administrator of PDXScholar. For more information, please contact pdxscholar@pdx.edu. 
SPEECH IMPROVEMENT AS AN AID TO

LANGUAGE DEVELOPMENT

by

MARILYN GOULD KNAUF

A thesis submitted in partial fulfillment of the requirements for the degree of

MASTER OF SCIENCE IN SPEECH COMMUNICATION:

with an emphasis in

SPEECH PATHOLOGY/AUDIOLOGY

Portland State University

1977 
TO THE OFFICE OF GRADUATE STUDIES AND RESEARCH:

The members of the Committee approve the thesis of Marilyn Gould Knauf presented May 6, 1977.

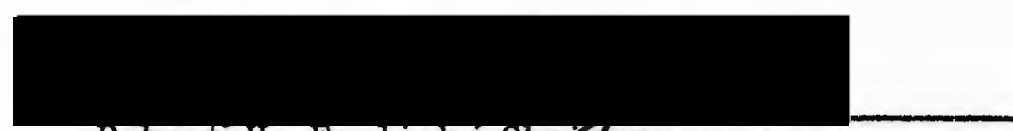

Robert H. English, Chay yman

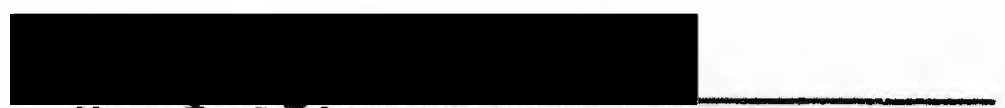

Mary E. Ggrdon

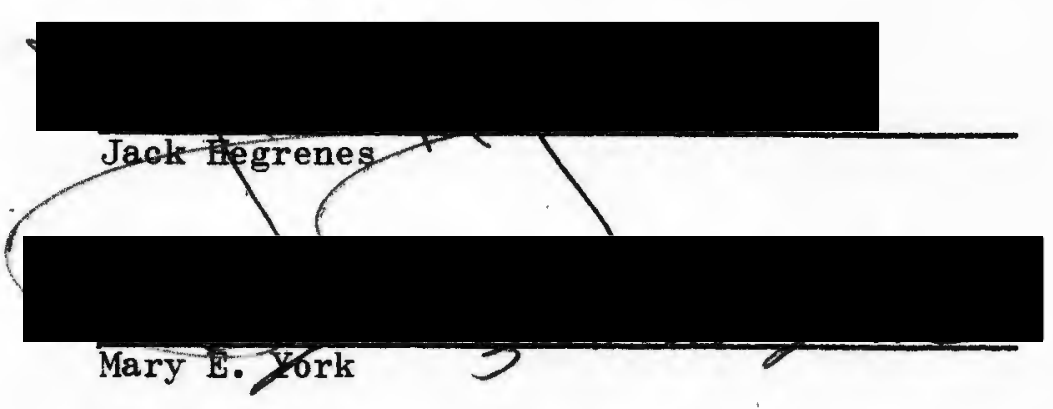

APPROVED:

Robert W. Vogelsapt, Chairmaz, Department of Speech Communication

Stanley E. Rauch, Dean, Graduate Studies and Research 


\section{ACKNOWLEDGMENTS}

With deep appreciation and gratitude I dedicate this thesis to Dr. Robert H. English, my advisor and committee chairman, who so willingly and generously gave of his time and assistance in this investigation of speech improvement, an area dear to his heart. I extend special thanks to my committee members Mary Gordon, Dr. Jack Hegrenes, and Dr. Mary York for their contributions, suggestions, and support.

To my wonderful husband, Edward, and my children, Diana, Jeffrey, Christopher, and Allie, my love and appreciation for their unfailing affection, support, and patience during my graduate study. This research was possible only through the combined efforts and giving of my family. Thank you! Also, I express thanks to my friends for their enc ouragement.

I would like to thank Dr. James Holmes, Irene Langston, Carol Erwin, and Julie McGrath of the Portland Public Schools for their cooperation in allowing this study to be conducted and a special thank you goes to the children of Mrs. Erwin's room at Humboldt School. The pleasure was mine!

This research was partially supported by a grant from the American Association of University Women, Project Renew, and it is gratefully acknowledged. 
TABLE OF CONTENTS

PAGE

ACKNOWLEDGMENTS . . . . . . . . . . . . . . . . . . ii

LIST OF TABLES . . . . . . . . . . . . . . . . . . . vi v vi

CHAPTER

I INTRODUCTION AND STATEMENT OF PURPOSE . . . . . . . . 1

Introduction ................ 1

Statement of Purpose .............. 2

Operational Definitions ............. 4

II REVIEW OF THE LITERATURE . . . . . . . . . . . . 5

Definition of Speech Improvement . . . . . . 5

Need for Speech Improvement . . . . . . . 7

The Clinician in Speech Improvement . . . . . 12

Classroom Teachers of Speech Improvement and

In-Service Training ............ 14

Administration of Speech Improvement . . . . . 20

Measuring Effectiveness of Speech Improvement . . 22

Model Programs ................ 31

Sumary and Conclusions . . . . . . . . 36

III METHODS AND PHOCEDURES . . . . . . . . . . . 38

Methods................. 38

Subjects

Instruments

Developmental Articulation Test 


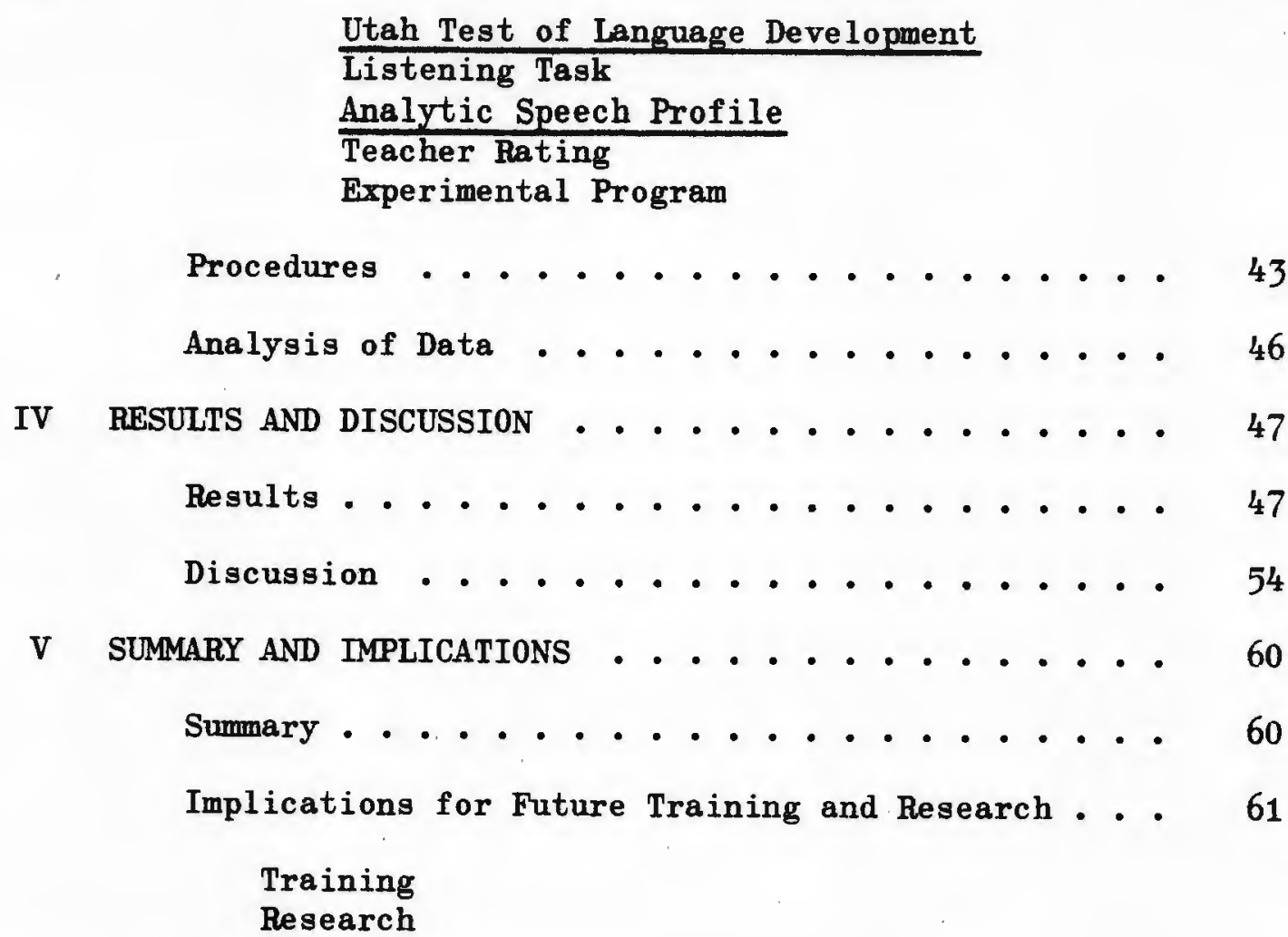

SELECTED BIBLIOGRAPHY . . . . . . . . . . . . . . . . 65 APPENDICES . . . . . . . . . . . . . . . . . . 71

A DEVELOPMENTAL ARTICULATION TEST . . . . . . . . . 72

B ANALYSIS SHEET . . . . . . . . . . . . . 73

C UTAH TEST OF LANGUAGE DEVELOPMENT, PLATE VT . . . . . . 74

D ANALYTIC SPEECH PROFILE . . . . . . . . . . . 75

E TEACHER RATING FORM . . . . . . . . . . . 76

F TEACHER RATING FORM . . . . . . . . . . . . 77

G PERMISSION REQUEST . . . . . . . . . . . . . 78

H SAMPLE LESSON PLAN . . . . . . . . . . . . . 79 


\section{LIST OF TABLES}

TABLE

PAGE

I TEST RESULTS FROM THE DEVELOPMENTAL ARTICULATION TEST SHOWTNG MEANS, STANDARD DEVIATIONS, AND t-TEST

RESULTS FOR BOTH PRE- AND POST-TESTS OF $\overline{2} 5$

KINDERGARTEN CHILDREN .............. 48

II RESULTS FROM THE ANALYTIC SPEECH PROFILE SHOWTNG

DISTRIBUTION OF SCORES FOR BOTH PRE- AND

POST-TESTS OF 25 KINDERGARTEN CHILDREN . . . . . . . 49

III TEST RESULTS FROM THE UTAH TEST OF LANGUAGE DEVELOPMENT

SEOWING MEANS, STANDARD DEVIATIONS, AND t-TEST

RESULTS FOR BOTH PRE- AND POST-TESTS OF

25 KINDERGARTEN CHILDREN . . . . . . . . . . 50

IV COMPARISON OF SCORES ON THE LISTENING MEASURE SHOWING MEANS, STANDARD DEVLATIONS, AND t-TEST RESULTS FOR BOTH PRE- AND POST-TESTS OF $\overline{2} 5$ KINDERGARTEN CHILDREN . . . . . . . . . . . . . . 51

V TEACHER RATING SCALE OF LISTENING SKILLS AND CLARITY AND WILLINGNESS OF EXPRESSION OF 21 KINDERGARTEN CHILDREN WITH A COMPARISON OF PRE- AND POST-PROGRAM SCORES AND THE DIFFERENCE AND SIGNED-RANK

DIFFEREINCE . . . . . . . . . . . . . . 52

VI RAW DATA FROM THE SUPPLEMENTAL TEACHER RATING FORM OF SPEYECH, LANGUAGE, AND LISTENING SKILLS AND LEVEL OF ENJOYMENT OF THE PROGRAM OF 25 KINDERGARTEN CHILDREN . . . . . . . . . . . . . . . . 
CHAPTER I

INTRODUCTION AND STATEMENT OF PURPOSE

\section{INTRODUCTION}

The literature suggests regular speech improvement sessions in kindergarten and first grade are beneficial (Van Riper, 1953; Garrison et al., 1961; Byrne, 1965; and Eisenson and Ogilvie, 1971). For example, in a comprehensive review of the literature Lysaght (1960) writes:

Speech improvement programs that have been initiated and carried on for a number of years are proving to be beneficial to the general speech of the total population and have reduced in numbers the minor speech problems.

It appears, however, few speech clinicians either engage in speech improvement or train classroom teachers to do so.

The American society seems to value good oral communication skills as Werner (1947) states: "Speech is not just an extra-curricular subject. It is an essential part of daily living and enters into every classroom activity." In a discussion concerning the development of oral communication skills in children Van Riper and Butler (1955) advise: "Our present culture is a highly verbal one. If we are to prepare our children to participate effectively in it, we must not neglect this most important phase." Students who fail to achieve competence in language are forced to face life with an unfair handicap for which the school must accept responsibility (Anderson, 1972).

Similarly, Shane and others (1961) contend: 
It seems an inescapable conclusion that an important reason for emphasizing language skills at the kindergartenprimary level is that language power serves to undergird the future academic progress of children more than does any other single asset that a boy or girl can develop.

Rasmussen (1962) reiterates:

Speech is man's way of understanding and living with other men . - and there can be no more urgent need on the part of a human being than to be accepted socially-to feel that he is appreciated and wanted in his group.

English (1960) also mentions the need of communication skills and the value of spoken language:

Children today . - have greater need for communication skills, particularly in the area of spoken language, than the children of generations past. The "speech needs" of all children, as well as the special needs of children with speech problems, should be of paramount importance to our entire society and particularly to our educators.

Speech improvement appears to be in a state of neglect. The communicative needs of all children require planned instruction in the skills of speaking. A modern language program should be concerned both with correct usage of the language and the development of personal expression (Anderson, 1972). It seems evident there is a need for further investigation designed to test the effectiveness of a planned program of speech improvement as an aid to the development of language skills.

STATEMENT OF PURPOSE

The purpose of this investigation was to examine and estimate the effectiveness of a group speech and language improvement program on the speech and language skills of children at the kindergarten level. The following goals were intrinsic to the project: 
(1) To stimulate language;

(2) To identify, discriminate, and produce speech sounds;

(3) To develop listening skills;

(4) To recognize good and poor voice quality; and

(5) To organize thoughts and express them clearly.

The primary question to be answered by this investigation was:

Generally, what are the effects of speech improvement and

language stimulation on articulation and speaking skills

of kindergarten children?

In seeking possible answers to this question the following five

null hypotheses were tested:

(1) No statistically significant difference will be present in the articulation skills of kindergarten children following the administration of a planned program of speech improvement and language stimulation.

(2) No statistically significant difference will be present in the vocal skills of kindergarten children following the administration of a planned program of speech improvement and language stimulation.

(3) No statistically significant difference will be present in the language skills of kindergarten children following the administration of a planned program of speech improvement and language stimulation.

(4) No statistically significant difference will be present in the listening skills of kindergarten children following the administration of a planned program of speech improvement and language stimulation.

(5) No statistically significant difference will be noted by the kindergarten teacher in the children's listening skills and ability to express ideas clearly and willingly. 
OPERATIONAL DEFINITIONS

The following are operational definitions of specific terms

employed in this investigation:

Speech: An acoustic event composed of three processes: phonation, articulation-resonance, and speech flow. Rate, loudness, pitch, voice quality, and articulation are basic to production of speech.

Language: The expression of communication of thoughts and feelings by means of vocal sounds, and combinations of such sounds to form meaningful units, as well as the reception and interpretation of these spoken units.

Listen: A receptive act which involves hearing, attending purposefully, recognizing spoken language, interpreting oral symbols, supplementing meaning and knowledge of the symbols from memory of past experiences and in terms of future needs, and being aware of facts or assumptions not uttered (Petrie, 1961).

Speech Improvement: A planned speech program conducted in a group setting wich is designed to assist children in the primary grades in the processes of improving their skill in the use of speech sounds, language, and listening, and guiding the normal development of these skills.

Speech Correction: Clinical services provided by a speech specialist and administered individually or in small groups of children for the purpose of ameliorating specific speech, voice, and language disorders. 
CHAPTER II

REVIEW OF THE LITERATURE

The present review of the literature concerning speech improvement will be presented under eight subtopical headings: Definition of Speech Improvement; Need for Speech Improvement; The Clinician in Speech Improvement; Classroom Teachers of Speech Improvement and InService Training; Administration of Speech Improvement; Measuring Effectiveness of Speech Improvement; Model Programs; and Summary and Conclusions.

\section{DEFINITION OF SPEECH IMPROVEMENT}

In defining the term "speech improvement," the consensus is that it is a systematic instruction in oral communication which takes place in the classroom (Garrison et al., 1961; Scott and Thompson, 1966; Van Hattum, 1969; and Eisenson and 0gilvie, 1971). English (1956) defines speech improvement as a planned speech program designed to assist children of the primary grades in the process of improving their skill in the use of speech sounds and speech.

Van Riper and Butler (1955) clarify the term by indicating that speech improvement is:

- - more than tongue exercises, memorization, vocal phonics, articulation drills, and activities. It is more than instruction in the improvement of voice quality, pitch, and intensity. Indeed, it is more than the sum total of all these parts. Speech improvement should go far beyond the mechanics of speech drills into the area 
of meaningful language. One of the most important aims might well be to help the children to verbalize their thoughts, to be able to "think on their feet" efficiently and adequately.

Scott and Thompson (1966), well-known authorities in the area of speech improvement, differentiate speech improvement from speech correction:

There is some obvious overlapping of speech correction and speech improvement . . . it is indicated that all children need help in developing and improving their oral communication skill, but all children do not have defective speech. Neither do children develop speech and language skills at the same rate or in the same way.

In 1960 the United States Office of Education, Purdue University, and the American Speech and Hearing Association undertook a national survey of speech and hearing services to schools in the United States. The goals of the project were:

(1) To describe current practices and trends in public school speech and hearing programs;

(2) To ascertain problems which could be resolved by systematic research; and

(3) To assign priority orders to these researchable areas (ASHA, 1961).

Speech improvement was one of the ten priority areas of study, and Work Group V, directed by Geraldine Garrison, investigated current practices of speech improvement and suggested outlines to follow in the administration of speech improvement. Work Group V proposed the following practical definition of speech improvement which appears to encompass all facets of the subject:

For the purpose of this study speech improvement takes place in the classroom. It consists of systematic instruction in oral communication which has as its purpose 
the development of articulation, voice, and language abilities that enable all children to communicate their ideas effectively. Speech improvement is not concerned with the work of the speech clinician with speech and hearing-handicapped children outside of the regular classroom (Garrison et al., 1961).

\section{NEED FOR SPEECH IMPROVEMENT}

Rasmussen (1962) states: "It is through speech that we express ourselves for either successful or unsuccessful living. Adequacy in self-expression obviously has much to do with the establishing of satisfying human relationships." Today, greater language power has been given mankind through the development of television, radio, and telephone. It is abundantly clear to thrive in a society dependent on communication, the inhabitants must develop the necessary language skills. Anderson (1972) advises: ". . the entire lifetime of an individual who reads with ease and expresses himself clearly and comfortably is a learning experience." It appears curious that the development of competent speaking and language skills should remain in a state of inattention, while accelerated concentration of factual information is consistently taught. The value of one without the other is negligible.

It is assumed the ability to express oneself adequately and easily develops spontaneously in a child (Van Riper and Butler, 1955). The development of speech, however, is the result of a long growth process. The mental and social aspects involving the development of speech in children is reviewed by Eisenson (1938):

From the very beginning of the child's conscious life, acts of behavior are accompanied by speech activity. At first the speech activity is as undifferentiated as the rest of the behavior, and is a mere by-product of the 
reflexive total bodily movements. In early childhood, speech accompanies most acts of behavior. Later, with further growth and maturity, speech frequently becomes a substitute for direct, overt behavior. The speech development of the individual parallels and reflects his intellectual, emotional, and physical growth. Nearly every conscious act of the person is verbalized, so that his speech represents a condensation of his entire cultural development; it is in effect a symbolization of the person's experiences resulting from the interactions of his innate tendencies and environmental influences. Because the entire person is involved in every speech act, speech reveals the state of the person at any given moment. The person is as he speaks.

Human beings are born with an innate capacity for learning language and a desire to communicate with other human beings (Perkins, 1971). Language development in children proceeds from communicating by cries to express hunger and pain, to the comprehension of a complicated set of codes which we call language. It is specified by Shane and others (1961) that the two types of communication skills which concern us in the early years are receptive and expressive language skills. Murphy and Leeper (1974) observe that once young children learn to use language the doors to communication open wider. Conmunication means both giving and receiving information; speech has no purpose unless it is associated with listening.

The innate tendencies and environmental influences (Eisenson, 1938) are coupled in the vital process of learning speech and being an active participant in communication. In discussing speech as a learned process, Werner (1947) describes the development of speech composed of the following elements:

Until some retardation in the "normal" acquisition of speech occurs, it is not realized that speech is a learned process. The learning of speech depends upon the stimulation of the desire to talk because of a need for speech, 
a readiness in maturation similar to the familiar "reading readiness," good patterns of speech for imitation, and encouragement in the building and in the establishing of correct habits of speech during the formative years.

In analyzing the development of language, Murphy and Leeper (1974) have made the following statement: ". . a kowledge of language helps a child to develop complex processes of thinking and to find solutions to problems." The development of vocabulary stimulates thought, and words become the tools of learning. Allen (1964) reviews some of the basic principles relative to language which educators need to understand and consider in recognizing language development:

(1) Language is a system which children learn by using, not by analyzing.

(2) Language is vocal and only speech provides all the essential signals.

(3) Letters are an attempt to represent the sounds of a language.

(4) Every language is unique in patterns, sounds, and syntax.

(5) Learning a language is governed by habits and situations.

(6) Language is for communication and meaning must be present for both the speaker and the listener.

(7) Language is related to culture and to speakers who are in certain places doing certain things.

(8) Language is always changing and is a viable product of usage.

The development of language is complex and dependent on many varying factors. Eisenson and Ogilvie (1971) outline the purposes and functions of language: 
- . to signal needs, intentions, thoughts and feelings;

to think; to control or direct one's own or others'

behavior; to express one's own feelings or to encourage

or distill aspects of feelings in others.

The life of a child is surrounded by speech. Speech is a part of his life from the moment he awakens in the morning until he falls asleep at night. His early years are spent in talking and making his wishes known. A child learns to use speech in getting along with others, in learning to take responsibility, in learning to think through problems. Speech is a natural and almost constant experience, as almost all social situations involve oral comunication (Scott and Thompson, 1955). Murphy and Leeper (1974) support the Scott and Thompson position when they declare: "A child who can't use words to expregs feelings will show anxiety in other ways-belligerent, withdrawn, babyish habits, wetting pants, and sucking thumbs." Eisenson (1938) emphasizes when mental and physical maturation progress smoothly, speech will develop steadily and evenly. Disturbances in mental and physical development, temporary or permanent, will be reflected in the individual's speech. Because continuous, undisturbed physical and mental development is rare, continuous and unimpeded speech development is exceptional. Rasmussen (1962) offers the following statement:

Speech is a complex act. A learned process, it is dependent upon desire and need for speech, upon good patterns for imitation, readiness in maturation, and encouragement and motivation for higher standards. The school will have to supplement the home in this educative process.

Van Riper and Butler concur when they write:

A few of our children have learned their techniques of oral communication fairly well; the great majority have not. Acquiring the skills of language... involves a 
change of behavior which persists and which is not due to maturation alone.

Physical maturation does influence behavior but learning may be described as a change which persists. Learning involves more than acquired skills. Knowledge and skill combined with a goal and an attitude of confidence embody learning. Anderson (1972) advises as educators influence the behavior of children in a learning situation, it may not be the task to teach a skill but to establish a goal for the child, or encourage him by building confidence.

The ability to express one's self with confidence and clarity is highly rewarded in society; therefore, attention must be focused early on how children talk.) According to Cole and others (1975), though only 10 to 20 percent of the kindergarten and first grade children will have articulation errors, all of the children need opportunities to modify their oral communication behaviors. Werner (1947) appears to support this position when she declared the teaching of talking must achieve an important place in education.

Thus, in summary, it might be concluded an individual's entire life is affected, positively or negatively, by his skill of communication. Language is the integral tool of thought, socialization, and communication. Children learn to talk before attending school, and they continue learning to talk, for better or worse, as long as they live. Rasmussen (1962) emphasizes that only through a systematic, orderly course of conscious speech education can children be taught to communicate effectively and efficiently. 
THE CLINICIAN IN SPEECH IMPROVEMENT

The continuum of speech clinician attitude toward speech improvement programs may best be described by English (1959) when he writes:

There are those therapists who refuse to become involved with such a program . . . there are those speech therapists who believe there is merit in speech improvement and they have combined it with their speech therapy programs to strengthen and enhance their speech therapy activities, and there are those . . who exuberantly go overboard for speech improvement while their speech therapy seems to fall by the wayside.

A national survey of speech improvement services (Garrison et al., 1961) reported that of the 245 persons who completed the questionnaires, 4 percent said they were speech improvement teachers, 11 percent speech and hearing therapists, and 80 percent classroom teachers. The nine school systems selected to participate in this study were ones which were known to have well-organized speech improvement programs in operation for some time. These programs were believed to represent a cross-section of speech improvement programs. The following communities participated in the study: Arlington County, Virginia; Brea, California; Des Moines, Iowa; Hartford, Connecticut; Hingham, Massachusetts; New York, New York; Wauwatosa, Wisconsin; Wichita, Kansas; and Youngstown, 0hio. In these nine school systems, it appears that the major responsibility for speech improvement instruction rests with classroom teachers.

ASHA (Garrison et al., 1961) specified that 11 percent of the persons teaching speech improvement are speech and hearing clinicians. Clinicians reported their duties included classroom demonstrations, coordination of speech improvement with both regular curriculum and 
speech and hearing programs, workshops, special meetings and programs, and assisting in evaluation of speech improvement. There was general agreement among supervisors and clinicians that clinicians should serve as consultants to teachers, but some supervisors and clinicians believe clinicians should teach speech improvement.

The above survey asked the question, "What is the speech and hearing clinician's relationship to the speech improvement program?" of the 141 supervisors answering, 20 percent replied the clinician teaches speech improvement, 17 percent replied the clinician supervises classroom teachers, 53 percent replied the clinician consults with teachers, and 8 percent had no participation. The 705 speech and hearing clinicians who answered this question reported that 22 percent taught speech improvement classes, 11 percent supervise classroom teachers, 49 percent act as consultants to classroom teachers, and 12 percent had no participation.

Freeman (1969) reports there are alternatives open to speech clinicians in acting as consultants to classroom centered speech improvement programs by providing guidance to teachers in organizing a curriculum. The clinician may find it helpful to arrange periodic demonstrations with entire classes, perhaps teaching the first in a series of speech improvement lessons and then turning it over to the teacher. The clinician may provide in-service training programs and reach larger numbers of teachers. The in-service training has the potential of developing an awareness of working together and fostering interest in developing an effective speech improvement program. Rasmussen (1962) agrees classroom teachers need training in oral communication because 
skills, understandings, and concepts of better speech must be taught by a teacher who has some knowledge of speech training.

It is prudent to remember the words of Van Riper and Butler (1955):

A good speech improvement program is of inestimable aid to the public-school therapist. It reduces her case load. It solves many of the difficulties in getting a child to carry over his newly acquired speech skills into his normal communication.

Irwin (1960) reiterates, the speech clinician will assist in the development of a speech improvement program only insofar as it enhances the speech rehabilitation of children receiving clinical speech services, but he will do all he can to encourage establishment of a speech education program with properly trained personnel. The ASHA report (Garrigon et al., 1961) specified that 61 percent of the clinicians polled stated there was no speech improvement work being performed in their schools. Speech improvement has unfortunately descended into the territory of "no man's land." For the lack of explicit job descriptions the important area of speech and language improvement is without specified leadership. The literature suggests the role of the speech clinician in speech and language improvement should be one of resource consultant, coordinator in curriculun development, evaluator of programs, and director of speech in-service workshops.

\section{CLASSROOM TEACHERS OF SPEECH TMPROVEMENT AND} IN-SERVICE TRAINING

The need for effective communication skills is established and whether the classroom teacher desires to purposefully instruct children 
in speech improvement or not, the very climate of the classroom dictates the amount and quality of verbal expression (Ogilvie, 1954; Van Riper and Butler, 1955; Rasmussen, 1962; Van Hattum, 1969; Eisenson and Ogilvie, 1971; and Anderson and Newby, 1973). Scott and Thompson (1955) further clarify this position when they write: "Every teacher is a teacher of speech, either consciously or unconsciously, for the speech habits and speech development of a child are affected and influenced by the activities that take place in the classroom." In 1947 Werner predicted the development of a new trend in education wherein every elementary teacher would have some training in speech correction, and special speech correction teachers would be provided for supervision in the larger school systems.

The elementary school curriculum, at present, does not include specific time for a program of speech training. Teachers often state certain amounts of time must be allotted to reading, spelling, arithmetic, social studies, science, music, and physical education, and there is no time left in a school day for a planned program of speech improvement. It has been said speech is taught all day long in connection with other subject matter and reading. Pronovost (1959) declares, in spite of the speaking ability a child brings with him to school, he needs the same systematic instruction in oral communication as he receives in reading, writing, and arithmetic if growth and development are to continue. If children are to develop skill in speaking and listening, they must learn how to talk and listen in an organized planned program of speech instruction. Schuell (1945) advises: 
A basic skill like speech which is closely related to social adjustment, to the development of the personality and to mental growth, should be a matter of serious consideration to every educator who cherishes the welfare of the child.

Research studies have shown the requirements for a successful

speech improvement program must include not only enough speech practice in stimulating situations and projects, but also one that provides for learning speaking skills under a competent teacher at a set time (Rasmussen, 1962). In outlining the responsibilities of elementary teachers in the teaching of speech, Huckleberry and Strother (1966) suggest factors which support Rasmussen. They write:

It is the responsibility of each elementary teacher (1) to assist the pupil in arriving at the level of adequate speech, (2) to motivate the pupil to go as far beyond adequacy as his capacity permits, (3) to provide speech experiences for the children for the pure joy and empathy of participation, and (4) to check and to improve her own speech.

The classroom teacher has the prime responsibility for activities in general speech and language improvement (Ainsworth et al., 1964; and Black, 1964). Elementary classroom teachers need to have a background in the speech development process and its disorders (Freeman, 1969). It is the role of the clinician in speech improvement to provide information, share techniques, and act as a consultant in the development of instructional procedures (Ainsworth et al., 1964). In meeting the obligations of a consultant in speech improvement activities the clinician must share his knowledge, and the most efficient means of doing so is through in-service training. The contributions of the speech clinician, in addition to in-service training, will be in providing teachers with special materials, discussing their uses, and possibly demonstrat- 
ing a sample speech and language improvement lesson (Black, 1964). School districts frequently offer in-service classes to teachers to help them develop skills and in many instances the employee receives credit and pay increments. The speech clinician is a specialist who has a vested interest in the quality of elementary language arts programs and who has the necessary skills and materials for teaching teachers in the skills of communication. In seeking ways of providing training through in-service, Freeman (1969) feels speech clinicians must first provide teachers with basic information concerning speech disorders before teaching methodology. The training programs could consist of in-service classes, sessions at workshops, lecture series, or short courses. All of these activities have proven effective in the business of establishing an awareness of the importance of speech skills. The goals of the speech clinician in conducting and instructing classroom teachers should contain, according to Anderson and Newby (1973), the following objectives:

(1) Impress the teacher with the importance of providing her pupils with a good model in her own speech, which, if not superior, should at least be free from defects.

(2) Acquaint her with the processes and factors involved in the child's natural speech and language development so that she will be prepared to facilitate that development and assist the child in establishing good habits of speech while he is young.

(3) Teach her to recognize and evaluate speech and hearing disabilities when she encounters them and instruct her where to turn for assistance with those problems she is not capable of handling for herself.

(4) Equip her to alleviate the simpler types of speech difficulties that can be adequately dealt with in a classroom situation with a minimum of technical knowledge and skill. 
(5) Train her to cooperate more effectively with the speech clinician.

(6) Impress her with the importance of oral communication and acquaint her with the relation of speech and speech defects to the personality development and behavior patterns of the child, to his progress in reading, and his achievement in the rest of his school subjects.

They conclude teachers must remember that speech, a basic function of the individual, cannot be separated from his other activities.

Many aspects of speech education are already an integral part of the present day curriculum in the elementary school. Van Riper and Butler (1955) compare the differences between the turn of the century classroom with its rigid and formalized manner of instruction and today's schoolroom which has smiling, laughing, and hums with talking while it discovers and learns through speech. Bennett (1971) quotes from the data collected at a conference on communicative disorders sponsored by the United States Office of Education: "Public school speech and hearing programs were perceived as being the most effective when integrally related to the total educational program ... and carried on as basic educational activities."

School districts may or may not require in-service classes in communicative skills for teachers, and it is the duty of a responsible clinician to take the initiative in organizing special teacher and parent training sessions in speech skills (Fisher, 1969). To aid speech clinicians in conducting workshops and in-service training sessions, Shine and Freilinger (1962) have developed Practical Methods of Speech Correction for the Classroom Teacher, which outlines speech services and coordinates the services with classroom activities to 
assist in carryover programs for speech handicapped children. The national survey (Garrison et al., 1961) of speech improvement services has indicated a need for more demonstrations, workshops, and conferences in speech improvement. This survey also stated, if classroom teachers are to benefit from methods, techniques, and materials currently in use, they must have available and take advantage of more adequate in-service training resources.

Unless the speech clinician provides the classroom teacher with explanations of who, why, and how certain children qualify for clinical services, it is impossible for teachers to understand the design and implementation of the speech clinician's program. In building satisfactory relationships with teachers, the clinician must have respect for teachers and their work. Powers (1956) presents guidelines and desirable qualities of an effective public school speech clinician. The clinician must demonstrate willingness to understand teachers' problems and opinions, the tact and efficiency in handling routine matters, the capacity to secure active interest and cooperation of teachers, inform teachers regularly of the speech progress of their pupils, and utilize opportunities to talk with teacher groups. In addition, clinicians need to be available to act as consultants on speech improvement activities in the classroom.

It is most unlikely a uniform method of speech training for classroom teachers will ever evolve. The school systems, curriculums, and classroom teachers are too diverse in scope to agree on speech training as a part of the established curriculum. Teachers must become aware of their responsibility in setting a good example in speech and poise for 
their pupils and also should teach speech in a planned program that goes beyond the average language arts program (English, 1958). It is abundantly clear, however, if teachers are afforded the opportunities to grow and develop their own speech skills and possess the knowledge and techniques necessary for teaching speech and language improvement to their pupils, they will "tackle" the task. The responsibility for instructing classroom teachers and conducting in-service training assuredly belongs to the speech clinician.

\section{ADMINISTRATION OF SPEECH TMPROVEMENT}

Based on the foregoing information, speech and language improvement must be an important segment of the total language arts program. The administration of speech improvement needs to be clarified and goal directed. Eisenson and Ogilvie (1971) outline the administration of a speech curriculum in elementary and high schools by designating three goals for each child:

(1) To correct any speech difficulty that calls attention to itself, causes the child undue concern, or detracts seriously from his communicative ability;

(2) To help him eliminate minor articulation and voice difficulties and nonstandard pronunciation if he and the teacher elect this option; and

(3) To assist him to become an effective speaker and listener.

In discussing these goals, Eisenson and Ogilvie (1971) indicated the speech and hearing clinician is responsible for the first, and the latter two aims are usually achieved by the classroom teacher in consultation with the speech clinician. The last two are generally included in 
a program called "speech improvement," "language arts," or "speech arts," and the responsibility for accomplishing them is likely to involve the remedial speech and hearing program as well as the language arts program of the classroom.

Garrison and others (1961) report that of the nine speech improvement programs studied, none followed a single administrative pattern. Five of them were part of remedial speech and hearing services; one was a separate speech improvement program coordinated with remedial services; one was an independent speech improvement program; one was identified with language arts but a speech clinician directed the work; and one was organized as a two-year research study directed by speech and hearing personnel. It was further reported (Garrison et al., 1961) that in seven of the nine school systems surveyed the supervisor of speech improvement received her major preparation and experience in remedial speech and hearing while the other two supervisors not only had preparation in remedial speech and hearing but also had additional education in speech arts, language arts, and speech improvement. Results surveying both supervisors and speech and hearing clinicians indicate speech improvement is primarily directed to kindergarten and primary grades, but it was the opinion of 61 percent of specialists interviewed that speech improvement should be a vital part of the curriculum from kindergarten through grade 12 (Garrison et al., 1961). The number of sessions per week varied from 1 to 5 , and the average length of a speech improvement session ranged from 15 to 24 minutes. It also was evident that the teaching of speech improvement is administered to all children in a classroom simultaneously. 
Information gathered by questionnaires (Garrison et al., 1961) from teachers of speech improvement indicates emphasis is placed upon speech sound discrimination. The children are instructed to identify and produce correctly all speech sounds. The goals of helping children to correct minor speech and voice problems, and to express their ideas clearly are emphasized. The results of this study specify that although much of the information on the effectiveness of speech improvement is based on judgment, it seems clear speech improvement has reduced the number of children needing clinical speech services, thereby reducing the case load of clinicians (Garrison et al., 1961).

It appears there are as many ways to administer speech improvement programs as there are programs. The need for cooperation between the classroom teacher and the speech clinician is vital to an effective speech improvement program and as English (1960) indicates, the visitations of a speech clinician to a classroom do not obviate the necessity for assistance from the classroom teacher in conducting a speech program. However varied the existing programs of speech and language improvement may be, it is evident comprehensive instruction designed to improve the speaking and language skills of all children is proving to be beneficial to the general speech of the total population (Lysaght, 1960)

\section{MEASURING EFFECTIVENESS OF SPEECH IMPROVEMENT}

In measuring the effectiveness of speech improvement, it was determined by the American Speech and Hearing Association Research Subcommittee (Garrison, Darley, Amidon, and Breinholt, 1961), ". . the 
principal means of measuring the effectiveness of speech improvement is the judgment of supervisors, teachers, parents, and children." Twentynine percent of the speech improvement teachers used articulation tests and 16 percent used voice ratings. Sixty-seven percent of the teachers depend on their own judgment, together with that of their supervisors, 31 percent use the judgment of parents, and 45 percent the judgment of children. Supervisors did not agree as to the extent to which speech improvement decreases the number of children requiring clinical speech services, but teachers of speech improvement are strongly convinced speech improvement aids children in developing good speech, voice, and language patterns, and assists in the correction of minor speech and voice problems. Speech improvement teachers also believe speech improvement lessons aid children in organizing their thoughts and expressing them clearly and effectively.

Scott and Thompson (1955) explain it is difficult to determine how effective certain speech improvement techniques are for the child with a speech problem when he is exposed to speech techniques in a group situation rather than on an individual basis. By using an articulation inventory it is possible, to a degree, to assess individual progress. An analysis of the following studies (Jones, 1951; Van Riper, 1953; Van Riper and Butler, 1955; Jones, 1957; Garrison et al., 1961; Sonmers et al., 1961; Rasmussen, 1962; Sommers, 1962; Sawyer, 1965; and Scott, 1968), reveals the effects of speech improvement on reading, speech, and language development when coupled with planned programs of speech and language improvement. 
Jones (1951) conducted a study investigating the effect of speech training on silent reading achievement. He administered speech training to normal third graders, and when compared to a similar control group, the group receiving speech training demonstrated significantly improved silent reading scores. Fundamental to this program of speech was instruction in attentive listening, methods of observation, and techniques of self-expression.

Van Riper (1953) conducted a pilot program with sixteen public school clinicians geared toward reduction of heavy case loads. The experiment sites were the public schools of Niles, Michigan, and the purpose was to combine clinical speech services and speech improvement with an end goal of reducing the clinical case load and increasing dismissals. Previous annual speech dismissals ranged from 11 to 21 percent. In October, February, and May all children receiving clinical speech services were examined by Van Riper. He reported that by February, under the new program, 38 percent of the cases no longer required speech services, and by May the total had increased to 51 percent. During this time span, all children enrolled in the first grade were administered weekly, half-hour sessions of speech improvement. In this pilot program, clinicians performed clinical work with speech handicapped children in the mornings and devoted afternoons to conducting speech improvement lessons for all first grade classrooms.

Wilson (1954) undertook a twelve-week study which pursued the effects of daily speech improvement lessons on kindergarten children; the following conclusions were drawn: 
(1) The reduction in the mean number of articulation errors made on sounds included in the speech improvement lessons is related to these lessons.

(2) The reduction in the mean number of articulation errors made on certain sounds not included in the speech improvement lessons is related to these lessons.

(3) Reading readiness scores as measured by the Metropolitan Readiness Test are not related to these speech improvement lessons.

The data collected on the third conclusion above was felt, by the author, to be inconclusive due to the unavalability of a valid testing instrument of pre-reading skills.

Jones (1957) conducted a speech improvement study with first grade children to determine the value of group speech instruction. A control group and an experimental group were given an articulation test at the beginning of the school year. The experimental group received daily instruction in speech for a twenty-minute period. At the end of the school year both groups were again tested on articulation ability. The following results revealed:

(1) Both groups as a whole demonstrated improvement in articulation.

(2) Some children in both groups demonstrated a loss in speech skills.

(3) Both groups improved more in sounds in the initial and final position. Children in both groups who omitted final sounds in the beginning of the year, correctly articulated them at the end of the year.

(4) Children in the experimental group who had the most serious speech problems at the beginning of the year, demonstrated the greatest improvement at the end of the year.

(5) Three children in the experimental group who demonstrated a loss in speech skills at the end of the 
year were explained: One had a hearing loss, and the other two had lost all of their incisors, making it difficult to articulate sibilants correctly.

(6) Fourteen children in the control group demonstrated a loss in speech proficiency, some serious and in all three positions.

(7) Final testing indicated the experimental group demonstrated a significant gain over the control group in correct articulation of sounds in the initial and medial positions.

Van Hattum (1959) researched a speech improvement program which consisted of listening or ear-training for all the first grade children of Rochester, New York. Children received ear-training for one school year with the clinician presenting the first lesson, followed by two more lessons per week taught by the teacher. Following the training period Van Hattum evaluated the number of children who required speech work in the third grade. Children numbering 1,503 had not received ear-training and 20.1 percent of them had speech errors. Of the 467 children receiving ear-training, 12.9 percent had speech errors. The number of dismissals increased from 19 percent to 41 percent. Van Hattum reported that observations revealed there did not appear to be a significant difference at the end of the first grade, but by the third grade there did appear to be. He also disclosed no real preparation time for lessons was required and the total time expended was seven hours.

Byrne (1960), through in-service training, taught teachers a program which utilized ear-training and emphasized identification of sounds, listening for sounds, and discrimination between sounds. The teachers provided kindergarten and first grade children with daily 
speech improvement lessons for twenty-one weeks. The children of the experimental groups were later compared with similar control groups. The experimental groups scored significantly better on several measures than the control groups. The kindergarten children in the experimental group achieved scores on two of three articulatory measures and one auditory discrimination test that displayed significant differences from the control group. The first grade experimental group scored on one articulation test that differentiated them from the control group; on word recognition the experimental first graders scored significantly better than the controls.

The effect of speech improvement and clinical speech services on reading skills and articulation of first grade children was investigated by Sommers and others (1961). Typical procedures in a speech improvement lesson consisted of teaching a sound for about four weeks. The entire class was taught to identify and discriminate this sound. Focus on ear-training exercises was used to strengthen perception of the sound. After the class appeared capable of making correct judgments on this sound, another commonly misarticulated sound was introduced. Individual performance and the use of mirrors were not utilized. It was established that speech improvement affected reading factor scores. Speech improvement appeared to be effective in producing significantly higher reading factor scores for first graders with normal articulation and misarticulation, e.g., twenty-five children with severe articulation disorders revealed improved reading scores when they received speech improvement lessons. Clinical speech services appeared not to have affected reading scores, but articulation did improve to a greater 
degree than with speech improvement alone. Three months of clinical speech services appeared about as effective as nine months of speech improvement in correcting articulation errors. Children who received regular speech improvement exhibited greater improvements in articulation skills than children who received no speech improvement. Children who had severe articulatory disorders improved significantly when receiving both clinical speech services and speech improvement when contrasted with a matched group who received only speech improvement. Sommers (1962) continued the previous study in which he tested the effectiveness of speech improvement on reading and articulation of school children beyond the first grade. Children who received speech improvement in the first and in part of the second grades scored significantly higher in reading factor scores than subjects who had no speech improvement. Since the study appears to have been carefully conducted over a long period of time, and included 1,250 subjects, it might be considered valid in reaching the following conclusions concerning articulation:

(1) Speech improvement conducted by clinicians who used analytical ear-training procedures was significantly better in improving articulation of first grade children when it was provided for 9 months rather than 16 weeks beginning at the middle of the school year.

(2) Speech improvement for 8 weeks in the second grade was ineffective in providing further improvement in articulation for children who received 9 months of it in the first grade.

(3) The consonant sounds most easily corrected under a program of 9 months of speech improvement in the first grade and 8 weeks in second grade were studied. They were found in order of highest to lowest percentage of correction to be: $/ v /, 50$ percent; $/ \mathrm{f} /, 41$ percent; $/ \mathrm{r} /, 38$ percent; $/ \mathrm{g} /, 37$ percent; $/ \mathrm{k} /, 36$ 
percent; $/ \theta /, 33$ percent; $/ \mathrm{s} /, 26$ percent; $/ \mathcal{S} /$, 22 percent; $/ t S /, 20$ percent; and $/ 1 /, 18$ percent. Additional investigation was given to the /s/ sound. Misarticulations of / $/$ / were analyzed in terms of interdental and lateral sigmatisms. Twelve percent of children with lateral sigmatisms were corrected; 32 percent of the children with interdental sigmatisms were corrected (Sommers, 1962).

The following conclusions were reached concerning reading:

(1) Subjects who were provided with speech improvement both in first and second grades made significantly higher reading factor scores at the end of the second grade than did subjects who were not provided with speech improvement.

(2) Higher reading factor scores for subjects who experienced speech improvement in first and second grades did not result in higher reading comprehension scores at the end of the second grade, compared to those who never received this treatment.

(3) No significant difference was found in the improvement of reading factor scores for first grade subjects who received 16 weeks of speech improvement compared with those who received 9 months of this treatment (Sommers, 1962).

Sawyer (1965) reported an investigation wherein practice in better speaking improved both silent and oral reading ability with a group of intermediate grade school children who were seriously retarded in reading. Children were trained to use correct articulation, pronunciation, gramar, sentence structure, and improved general speech habits. It was noted the children's speech demonstrated decided gains. They spoke more fluently, and their enunciation was improved. The children also showed noticeable gains in poise and confidence. Classroom teachers observed the children and noticed they were more confident, more willing to volunteer during discussions, and more willing to give oral reports. One teacher reported that the five children who had 
participated in the program wrote more readily and had much more to say. The teachers in this school developed a new awareness of the link between speech and reading. "They approach remedial work with twin problems in mind, for they have been alerted to the fact that speech plays an important role in reading" (Sawyer, 1965).

English (1957) reports on teacher evaluations of a planned program of speech improvement conducted in the schools of Lake Oswego, Oregon. Almost unanimous approval of speech improvement was expressed by the teachers. It was noted all teachers felt the children enjoyed the speech program and there was adequate correlation between the speech improvement program and other speech and phonics activities in their classrooms. The majority of teachers felt children profited from the speech improvement lessons.

In an overview of the literature the following conclusions may be drawn as to the characteristics and effectiveness of speech improvement programs :

(1) Children's speech does improve through programs of speech and language improvement.

(2) Most children do improve in articulation skills due to maturation.

(3) Speech defects may be related to reading difficulties.

(4) Acceleration of reading progress often follows a speech improvement program.

(5) Many children need help in the process of learning to speak correctly.

(6) Faulty speech may cause lack of academic progress.

(7) Most children can benefit from improving their ability to think on their feet. 
(8) Most children can develop a consciousness of good voice quality.

(9) Speech improvement, to be effective, must be taught as a separate subject, and additionally correlated with other expressive areas in the language arts curriculum.

(10) Ear-training is effective in improving reading and speaking abilities.

MODEL PROGRAMS

It seems obvious that schools need both clinical speech services and speech improvement programs (Eisenson and Ogilvie, 1971). Clinical speech services aid the handicapped and speech improvement helps all children speak and listen better. Democratic and friendly classrooms promote and stimulate speaking activities. The following section illustrates how programs may be organized and what are necessary attributes of an effective speech improvement program.

According to Scott and Thompson (1955), the most valuable speech improvement program would be one that integrates speech activities so thoroughly into the daily curriculum that it becomes a part of every learning activity and children should expect it daily. It should not proclaim that it is speech for the sake of speech, but speech as a vehicle in improving one's ability to communicate effectively with others. Rasmussen (1962) disagrees with the Scott and Thompson position of integrating speech activities and not calling attention to speech for the sake of speech. She reiterates, surely good speech education must be integrated in the total learning and living activities, 
but it does not mean speech instruction must be indirect. Speech is best learned and taught if there is total awareness of the meanings and values of speech. "Speech instruction will achieve best results when taught directly" (Rasmussen, 1962). Because speech is a tool, just as reading and writing are tools, it must be taught directly to develop its maximum potential.

To incorporate oral language skills into the curriculum it must be considered that a classroom of children will reveal varied differences in the rate of learning, social and economic backgrounds, interests, and dozens of other factors which require recognition. The teacher knows the WHOLE child comes to school, not just a mind to be taught (Anderson, 1972). In organizing and planning speech improvement activities the following statements by Low (1955) concerning the learning process are worthy of consideration:

(1) A child learns best when he is relieved of too great pressure to compete and when he feels reasonably confident that he can accomplish what is expected of him.

(2) Learning takes place more readily if the child accepts as useful and important to him the activities in which he is expected to engage.

(3) Learning is facilitated and reinforced when more than one sensory approach is used.

(4) Learning is more efficient if it has satisfying emotional content, if feeling is supportive of thinking.

(5) Attitudes, feelings, values, and appreciations are learned. Every experience involves a constellation of such learnings.

Scott and Thompson (1955) agree with Low concerning the avenues of learning, stating exciting instructional materials are needed for young 
children, especially ones which sharpen their senses to sights, sounds, tastes, smells, and textures and which allow receptiveness to learning through their senses.

Work Group V, in the national survey of speech and hearing services to schools (Garrison et al., 1961) suggest a model program for speech improvement based on programs in progress at that time. The recommendations may be summarized as follows:

(1) Classroom teachers need assistance in helping all children to organize their thoughts and express them effectively, using the best speech, voice, and language possible.

(2) Speech and hearing personnel screen and keep records on all children.

(3) In-service training which includes workshops should be given to classroom teachers for a period of two to three years.

(4) Speech improvement activities are part of the regular curriculum from kindergarten through grade 12.

(5) Speech clinicians provide once a week demonstrations during the in-service period.

(6) Attention is given to the correction of minor speech and voice problems.

(7) The speech clinician is available to the teacher for conferencing.

(8) The speech clinician assists the teacher in using standardized measures of evaluation.

(9) The teacher assumes responsibility for speech improvement once the in-service is completed, and uses the clinician as a resource consultant.

Van Riper (1953) supports the position of the promotion of speech for the sake of speech and includes the following goals for a speech improvement program: 
(1) To help the children identify and recognize the characteristics of the isolated speech sounds, a goal which pays dividends not only in terms of better speech but also in improving other basic skills needed in school;

(2) To improve the child's vocal phonics so that he can not only learn new pronunciation easily but also through the analysis and synthesis training come to attain the phonic skills necessary in reading and spelling;

(3) To interest the child in the correction of articulation errors without penalty;

(4) To help the child explore the geography of the mouth and improve the coordinations required for adult speech;

(5) To improve his fluency and to resist those influences tending to disrupt fluency:

(6) To improve his ability to think upon his feet by training in self-talk, in commenting aloud on what he perceives, does, feels;

(7) To create consciousness of good voice quality as a basic asset;

(8) To assist the child in learning how to project and monitor the intensity of his voice; and

(9) To help the child express his conflicts and feelings through training in speech hygiene.

Van Riper (1953) concludes by recommending the above activities for all children, stating there are special advantages to children with defective speech. Clinicians who avoid speech improvement should be cognizant of some of the benefits derived from speech improvement, such as increased cooperation of classroom teachers, increased motivation of children, and better carry-over of newly acquired speech skills.

Although emphasis has been placed on meaningful and functional language experiences for children, such experiences must not be left to 
chance or taught in an incidental manner. Shane and others (1961) propose the following suggestions for improving children's expression which ascertains that grammar, interpreted as good usage, can be deliberately woven into the kindergarten primary years. The effective language usage program in the early grades is one in which:

(1) The teacher presents a good example of speech skills and poise.

(2) The opportunities for speaking are plentiful.

(3) Children are not nagged about faulty speech, but presented with good examples of usage.

(4) Obscure errors are ignored, while commonplace errors receive attention.

(5) The readiness for usage is regularly encouraged.

(6) Good usage is learned by using, rather than by rules.

(7) Resources such as sharing, reading, and relating experiences are recognized and utilized as methods for improving language usage.

(8) The understanding of simple and familiar items comes first.

(9) Children are never made to feel self-conscious or uncomfortable about their language usage. Kindness is paramount.

(10) The teacher must be aware of the varied backgrounds of her pupils. Rate of growth rather than the level of ability is the most significant aspect of progress (Shane et al., 1961).

It is the consensus of the following authors that all children can profit from a program which helps them to listen, to enunciate carefully, and to speak with a pleasant voice that displays good vocal variety (Scott and Thompson, 1955; Van Riper and Butler, 1955; and Garrison et al., 1961). This point of view is supported by a special ASHA 
report (Garrison et al., 1961) which acknowledges educators and parents are developing an awareness of the need for all children to develop the ability to communicate their ideas capably with patterns of speech which are acceptable in speech, voice, and language. For speech education to be effective it must be built upon an understanding by children of good speaking standards, a desire to improve their speech habits through practice, and regular opportunities to participate in expressing themselves enjoyably. Activities for speaking should provide the children with practice in using good speech habits and ideally provides opportunities for the development of self-confidence in meeting all types of situations with ease (Werner, 1947).

SUMMARY AND CONCLUSIONS

For convenience of discussion, the literature dealing with speech and language improvement has been presented under seven topical headings: Definition of Speech Improvement; Need for Speech Improvement; The Clinician in Speech Improvement; Classroom Teachers of Speech Improvement and In-Service Training; Administration of Speech Improvement; Measuring Effectiveness of Speech Improvement; and Model Programs. From the existing data it has been noted speech and language improvement is a valuable part of the school curriculum, especially at the preschool and primary level.

We live in a society where the mastery of the skills of language is an essential factor to the success of an individual. Too much of the teaching of language skills in the elementary school still remains at an ill-defined and experimental level (Huckleberry and Strother, 
1966). Language and learning are so inextricably interwoven that the fabric of an individual is dictated by his skill with language and ability to analyze information. Life experiences demand a person possess a certain degree of verbal expression and the ability to think on one's feet. Children must learn to hear, understand, remember, and discern because all are involved in the difficult task of listening (Huckleberry and Strother, 1966). Throughout life an individual learns essential knowledge through various modes of language and it is of supreme concern that we prepare and arm our youth with the necessary skills of communication.

Murphy and Leeper discuss the ramifications involved in the communication process when they write:

Many of today's problems have come about because there has been too little communication among different groups within our population. Perhaps, if our children learn both to cormunicate clearly and listen attentively, as adults they will be able to communicate with one another to bring about a better tomorrow.

Anderson and Newby (1973) conclude that, educationally speaking, we may have been guilty of getting the cart before the horse in stressing the importance of written language without first making sure the child possessed adequate ability in oral communication. 
CHAPTER III

METHODS AND PROCEDURES

METHODS

Subjects

Twenty-five children enrolled in a kindergarten class at Humboldt Elementary School, Portland Public Schools, Portland, Oregon, were the subjects of this study. Three other children in the classroom were receiving the clinical services of a speech clinician, and while they were present for the speech and language improvement program, they were not included as subjects. The children were from varied socioeconomic levels and were multiracial. Additionally, it should be noted the teacher of this classroom was desirous of speech improvement activities, thus creating a conducive climate for the program.

Children included in the investigation ranged in age from 5.1 to 6.4 years of age. Sixteen of the children were male and nine were female. During the third week of the speech improvement program each child was screened for auditory acuity. All but two children passed a bilateral, puretone, audiometric sweep scan at $20 \mathrm{~dB}$ (ISO) for the speech frequencies of $1 \mathrm{~K}, 2 \mathrm{~K}, 4 \mathrm{~K}$, and $6 \mathrm{~K} \mathrm{~Hz}$. administered by a state audiometrist using a Beltone Audiometer (Model 10D) with Western Electric headphones.

Speech. All subjects, except the three receiving speech services, were given an articulation test by the examiner to determine their 
current proficiency with various speech sounds in initial, medial, and final positions of words. Seventeen different consonant phonemes and an additional 5 blends were tested for a total of 54 items. A score of 52 was considered criterion for passing the articulation test.

Language. A screening test of language development was administered to note the possibility of the presence or absence of language delays and/or disorders. Correct responses to the five items presented were required to pass criteria.

Voice. The vocal parameters of rate, loudness, and pitch were judged by the examiner during the administration of the articulation and language screening tests.

Listening. The screening test of listening was administered following the above instruments and is a gross measure based on the established practice in the measurement of listening as described by Nichols and Lewis (1963).

Instruments

Tests. The He jna Developmental Articulation Test (1963) was employed, in part, as the instrument for assessing articulation proficiency. The following sounds were tested in initial, medial, and final positions :

$$
\begin{aligned}
& / \mathrm{b} /, / \mathrm{k} /, / \mathrm{g} /, / \mathrm{f} /, / \mathrm{j} / \mathrm{g} /, \\
& / \mathrm{d} /, / \mathrm{l} / \mathrm{r} /, / \mathrm{t} /, / \mathrm{s} / \mathrm{d} / \mathrm{t} /, \\
& / \mathrm{v} /, / \theta /, / \mathrm{d}_{3} /, / \mathrm{s} /, / \mathrm{z} /, \text { and } \\
& \text { blends } / \mathrm{dr} /, / \mathrm{kl} /, / \mathrm{bl} /, / \mathrm{gl} /, / \mathrm{kr} /
\end{aligned}
$$

These sounds were selected because they are developmentally produced by 
the age of seven by 90 percent or more children (Hejna, 1963). Colored pictures were used to elicit spontaneous speech responses. A sample scoring blank with the words represented by the pictures on the Hejna Developmental Articulation Test may be found in Appendix A.

Recording the results of this screening test of articulation is provided after each set of test items for each subject's responses.

Three common types of errors scored are as follows:

Substitution: The use of one speech sound in place of another.

Distortion: The faulty production of a speech sound, although the sound produced is recognized as being an example of the desired phoneme.

Omission: The failure to produce a sound in the position where it normally should occur, and failing to insert any other sound in its place (Johnson et al., 1963).

An analysis sheet was attached to the Articulation Scoring Blank which allowed further analysis of the number of errors, position of errors, and type of errors (omissions, substitutions, or distortions). See Appendix B for a sample analysis sheet. A numerical value of one was assigned for every item on the test.

The screening version of the Utah Test of Language Development by Meacham, Jex, and Jones $(1967 ; 1973)$ was administered to detect any possible presence or absence of delayed or disordered language. This screening test is composed of 5 items and takes about $2 \frac{1}{2}$ minutes to administer. It has a 100 percent correlation with the complete or fullscale version of the Utah Test of Language Development (1967). The following items comprise the screening test: 
(18) Names common pictures. Show pictures on Plate VI. (See Appendix C for Plate VI.) The pictures the child is requested to name are: wagon, cat, dog, shoes, car, book, boy, girl, house, light, candy, hand, and fence. If the child names twelve or more correctly, score the item plus.

(19) Says at least one nursery rhyme. Must say in correct sequence and without promptings. May leave out no more than two or three small incidental words. If the child says one nursery rhyme adequately, score the item plus.

(21) Names colors. Show child Plate VII. If the child names five or more colors correctly, score the item a plus.

(24) Can repeat a twelve syllable sentence. No error is permitted. Errors include omissions, substitutions, additions, changes in words or in order of words. Articulation errors are not penalized. If the child repeats one sentence correctly with no word errors, score item plus. Do not repeat sentence.

(26) Can copy a square. Have pencil or crayon and present square on score sheet. If child copies one square acceptably out of three trials, score it $\overline{e m}$ plus. Square must have fairly straight lines and no round corners and no ears.

The measurement of listening consisted of reading a paragraph from a children's book (Viorst, 1969) which contained seven thoughts and/or phrases. The child was read the paragraph (no visual clues presented), and then asked to tell the examiner what it was about. Criterion for passing this test was recollection of four of the seven thoughts.

Voice. Three elements of speech were rated: time (rate), loudness, and pitch. A standard speech evaluation form, the Analytic Speech Profile (Henley and Thurman, 1970), was employed in part. A rating scale ( 1 through 7 , with 4 judged as normal) was used. Criteria for success was 4 (normal) or above in all 3 elements. (See Appendix D 
for a copy of the Analytic Speech Profile.)

Teacher Rating. The classroom teacher was asked to evaluate each child in the areas of clarity of expression, speaking willingly before the group, and level of listening skills. A scale of -2 to +2 was employed with zero being average. The three scores were added, resulting in a combined score which had the range of -6 to +6 . The preprogram form may be found in Appendix E. A post-program teacher rating form was employed using the same scale $(-2$ to +2$)$. It included the areas mentioned above and also requested teacher judgment on how much each child improved in the areas of speech and language skills, listening skills, and enjoyment of the program. Refer to Appendix F for the post-program form.

Approval Forms. Written permission from the parents of the children to be involved in the study was secured before initiating either the testing or speech and language improvement program. The parental permission form may be found in Appendix G.

Experimental Program. The speech improvement program used by this investigator was Louise Binder Scott's (1971) Learning Language Skills-I, which was designed for ages four through six. The general objectives of the program are:

(1) Use the child's environment as a springboard for stimulating language.

(2) Provide a combination of sensory experiences (auditory and visual) that stimulate language development.

(3) Introduce poetry and literature.

(4) Provide materials that aid in concept development. 
(5) Develop listening skills and oral competency.

(6) Make all language experiences happy, enjoyable, and satisfying.

The program consists of twenty large story cards, each of which promotes the usage of a specific phoneme. There is a large book with pictures, on which each page emphasizes a particular phoneme; in the center of the book is a circular mirror. A small set of pictures which match the large book is included. A hand puppet named "Honey Bear" is supplied with the most important purpose of the puppet being to stimulate language and trigger creative expression. Two concept development books, "Teeny Mouse and Tiny Mouse" and "Who Are We?" complete the program materials. A guide book with instructions and sample lesson plans is provided.

\section{PROCEDURES}

Approva 1

Permission to conduct the investigation was received from $\mathrm{Dr}$. James Holmes, Area I Administrator, Portland Public Schools.

Permission forms were secured from the parents of each child in the classroom prior to initiating the speech and language improvement program.

\section{Experimental Instructional Program}

The program consisted of sixteen half-hour sessions taught over a period of eight weeks. This clinician presented lessons each week on a particular phoneme using materials of the Learning Language Skills-I program (Scott, 1971) and suggested enrichment activities. The 
following phonemes were taught: $/ \mathrm{b} /, / \mathrm{w} /, / \mathrm{h} /, / \mathrm{t} /, / \mathrm{d} /, / \mathrm{k} /, / \mathrm{g} /$,

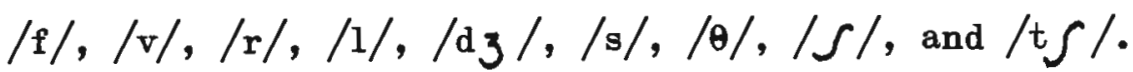

Administering Tests

The Developmental Articulation Test (Hejna, 1963) was administered, in part, to each child individually at a table in the hall of the school. The screening form of the Utah Test of Language Development (Mecham et al., 1967, 1973) was administered after the articulation test. The voice rating, Analytic Speech Profile (Hanley and Thurman, 1970), was used to judge each child as he/she said the nursery rhyme for the language test. When no nursery rhyme was spoken, the child was requested to say numbers, name and address, or the alphabet. The measurement of listening ability was administered after the language and voice tests. These four instruments were used as a pre-test battery and also as a post-test battery at the conclusion of the speech improvement program. Each subject's pre- and post-test scores were then compared to note any possible improvement. While test scores may be of value for indicating a child's progress toward certain goals, the classroom teacher's judgment as she observes the child's behaviors and interactions in his environment is of considerable worth. Hence, the classroom teacher was asked to evaluate each child in light of what she observed, using rating forms. She rated each child both before the speech and language program began, and after it was concluded. (See Appendices $E$ and $F$ for the teacher rating forns.)

The Developmental Articulation Test (He jna, 1963) was administered in the following manner: 
The child was told he was going to look at some pictures and tell what he saw. Each response was noted on the record form before presenting the next stimulus. A prompting phrase was used only if the child did not produce a spontaneous response to the picture stimulus. Reinforcement was used for cooperation and effort, not for correctness of speech production.

The screening portion of the Utah Test of Language Development (Mecham et al., 1967, 1973) was administered and scored as described under the "Instruments" section above.

The Analytic Speech Profile (Hanley and Thurman, 1970) was used to rate each child's voice during the administration of the language test. This procedure also was described in more detail above under "Instruments."

The listening measurement was administered in the following manner:

The child was told he was going to listen to part of a story and was instructed to listen and remember as much as he could. At the completion of the paragraph the examiner made the statement: "Tell me all you can about the story." The child's responses were then recorded on the reverse side of the form. Here, again, reinforcement was used for effort, not for correctness of response.

\section{Administering Experimental Program}

The general procedures followed in using the Learning Language Skills-I program (Scott, 1971), hereafter referred to as LLS, were: reading an LLS Story Card; asking the children for comments about the 
story card; asking the children if they heard the sound when they named the pictures in the LIS Mirror Book; asking them to watch you as you said the sound; instructing them to make the sound; asking children if the sound was in their name anywhere; asking children to stand if their name began with the sound; asking children to look around the room for objects that had the sound in them; asking questions about the pictures in the LLS Mirror Book which required thinking; asking questions which required reasoning, i.e., "What would happen if ?"; matching Small Picture Cards to those in the LLS Mirror Book; encouraging sentence responses by asking "What am I doing?"; asking children to describe how an object felt; asking children to describe how they would feel if ; and using finger plays and poems to allow practice of the sound. (See Appendix H for a sample lesson plan.)

\section{ANALYSIS OF DATA}

Comparisons of pre-program and post-program performance on articulation, voice, language, listening, and teacher rating were made. Mean scores and standard deviations were determined in articulation, language, and listening, and the differences between the before and after means were analyzed by means of the $t$ test, utilizing a onetailed distribution (Siegel, 1956). The Wilcoxon matched-pairs signedrank test (Siegel, 1956) was used for the pre- and post-program teacher rating scale.

The level of significance chosen for rejection or acceptance of the null hypotheses was determined at the $\mathrm{P}<05$ level of confidence. 
CHAPTER IV

\section{RESULTS AND DISCUSSION}

\section{RESULTS}

This experimental study sought to investigate the effects of a speech and language improvement program on the developing speech and language skills of a group of kindergarten children. At the outset of the investigation each child in the classroom was evaluated, utilizing the test instruments described in Chapter III, to determine his/her level of proficiency in articulation, voice, language, and listening ability. Following this evaluation the children, as a group, participated in an eight-week speech and language stimulation program consisting of thirty-minute sessions taught by the investigator on a biweekly basis. The nature of these lessons has been thoroughly detailed in the previous chapter. At the conclusion of the training program the children, individually, were once again evaluated, utilizing the same instruments used in the pre-test. Additionally, the classroom teacher rated each child relative to clarity of expression, willingness to speak before the group, and ability to listen on a pre- and post-test basis.

Results of the several evaluation instruments were then compared in order to answer the following question:

Generally, what are the effects of speech improvement and language stimulation on articulation and speaking skills of kindergarten children? 
The null hypotheses tested were:

(1) No statistically significant difference will be present in the articulation skills of kindergarten children following the administration of a planned program of speech improvement and language stimulation.

Means, standard deviations, and the t-test relative to the preand post-test results, using the Developmental Articulation Test (He jna, 1963), are presented in Table I. Here it can be noted is a significant difference before and after the training period with a onetailed $t$ score, 2.55, d.f. 48, with $P \ll 01$. Based on this finding the null hypothesis is rejected. More specifically, children do show a marked significant gain in their articulation test scores following an eight-week training session in speech improvement.

\section{TABLE I}

TEST RESULTS FROM THE DEVELOPMENTAL ARTICULATION TEST

SHOWTNG MEANS, STANDARD DEVIATIONS, AND t-TEST

RESULTS FOR BOTH PRE- AND POST-TESTS

OF 25 KINDERGARTEN CHILDREN

\begin{tabular}{lccc}
\hline & Pre-Test & Post-Test & $\underline{t}$ \\
\hline Mean & 50.68 & 52.76 & \\
S.D. & 0.5446 & 0.1169 & $2.55^{*}$ \\
\hline
\end{tabular}

$* \mathrm{P}<01, \mathrm{~d} . \mathrm{f} .48$. 
(2) No statistically significant difference will be present in the vocal skills of kindergarten children following the administration of a planned program of speech improvement and language stimulation.

Pre- and post-test results of the Hanley-Thurman (1970) Analytic Speech Profile used in rating the vocal parameters of time (rate), loudness, and pitch are presented in Table II. Inspection of the raw data ratings on a 7 point scale reveal no significant differences exist in the three parameters between pre- and post-test rating results. Hence, no further statistical analysis was performed on these data. It should be noted from Table II that 18 scores might be considered as "normal" under pre-test conditions with 22 falling within the "normal" range on the post-test. Based on these findings the null hypothesis is accepted.

TABLE II

RESULTS FROM THE ANALYTIC SPEECH PROFILE SHOWING DISTRIBUTION OF SCORES FOR BOTH PRE- AND POST-TESTS OF 25 KINDERGARTEN CHILDREN

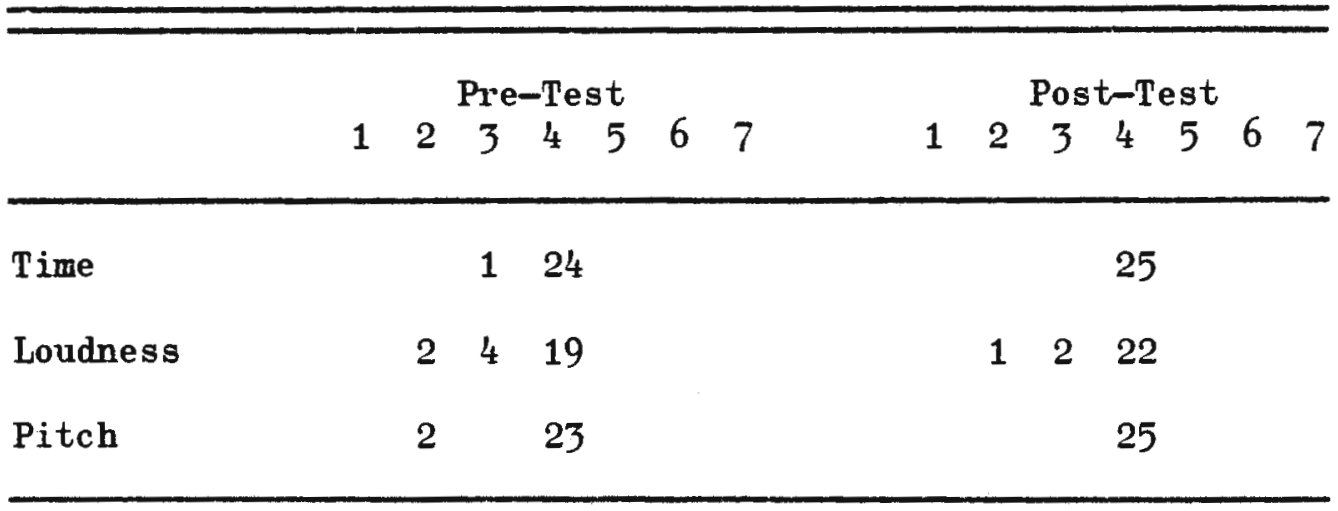


(3) No statistically significant difference will be present in the language skills of kindergarten children following the administration of a planned program of speech improvement and language stimulation.

Table III contains the means, standard deviations, and t-test results, using the screening test of the Utah Test of Language Development (Mecham et al., 1973). The data reveals no significant differences were present in the language skills of these kindergarten children; hence, the null hypothesis is accepted. To be significant at the .05 level $P$ would have to equal or exceed 1.67

\section{TABLE III}

TEST RESULTS FROM THE UTAH TEST OF LANGUAGE DEVELOPMENT SHOWING MEANS, STANDARD DEVIATIONS, AND t-TEST RESULTS FOR BOTH PRE- AND POST-TESTS OF 25 KINDERGARTEN CHILDREN

\begin{tabular}{lccc}
\hline & Pre-Test & Post-Test & $t$ \\
\hline Mean & 3.48 & 4.64 & \\
S.D. & 1.426 & 0.70 & $1.33^{*}$ \\
\hline & *P>.05, d.f. 48.
\end{tabular}

(4) No statistically significant difference will be present in the listening skills of kindergarten children following the administration of a planned program of speech improvement and language stimulation.

In Table IV the means, standard deviations, and resultant t-test score are to be noted. In this case $t$ was found to be 7.642 with a $\mathrm{P}<.0005$ on a one-tailed test. Hence, the null hypothesis is rejected. 
The children used in this study showed a very significant gain in preand post-test listening scores after an eight-week speech and language program, which included training in listening skills.

TABLE IV

COMPARISON OF SCORES ON THE LISTENING MEASURE SHOWING MEANS, STANDARD DEVIATIONS, AND t-TEST RESULTS FOR BOTH PRE- AND POST-TTESTS

OF 25 KTNDERGARTEN CHILDREN

\begin{tabular}{lccc}
\hline & Pre-Test & Post-Test & $t$ \\
\hline Mean & 2.36 & 3.8 & \\
S.D. & 1.675 & 1.60 & $7.642^{*}$ \\
\hline
\end{tabular}

${ }^{*} \mathrm{P}<0005$, d.f. 48.

(5) No statistically significant difference will be noted by the kindergarten teacher in the children's listening skills and ability to express ideas clearly and willingly.

A teacher rating scale was employed for the purpose of determining whether the skills learned during speech improvement and language stimulation activities would generalize to the classroom setting. The teacher noted improvement in the children's listening skills and ability to express ideas clearly and willingly in all subjects except four children, wherein they were rated the same $(+4,+5,+6,+6)$, that is, at the top of the scale.

Visual inspection of Table $V$, the teacher rating scale, reveals differences to be highly significant. It is to be observed in Table V four children were excluded as specified by the Wilcoxon matched-pairs 
TABLE V

TEACHER RATING SCALE OF LISTENING SKILLS AND CLARITY AND WILLINGNESS OF EXPRESSION

OF 21 KINDERGARTEN CHILDREN WITH A COMPARISON OF PRE- AND POST-PROGRAM SCORES AND THE DIFFERENCE AND SIGNED-RANK DIFFERENCE

\begin{tabular}{|c|c|c|c|c|c|c|c|c|c|}
\hline Subject & Pre- & Post- & Di & $\begin{array}{c}\text { Rank } \\
\text { Differ- } \\
\text { ence }\end{array}$ & Subject & Pre- & Post- & Di & $\begin{array}{c}\text { Rank } \\
\text { Diff er- } \\
\text { ence }\end{array}$ \\
\hline 1 & +3 & +5 & 2 & 5.5 & 12 & -6 & 0 & 6 & 21 \\
\hline 2 & +2 & +4 & 2 & 5.5 & 13 & +5 & +6 & 1 & 2 \\
\hline 3 & -2 & +2 & 4 & 11.5 & 14 & -1 & +3 & 4 & 11.5 \\
\hline 4 & -5 & -2 & 3 & 8.5 & 15 & -3 & +2 & 5 & 17 \\
\hline 5 & +3 & +5 & 2 & 5.5 & 16 & -2 & +3 & 5 & 17 \\
\hline 6 & -5 & 0 & 5 & 17 & 17 & +4 & +6 & 2 & 5.5 \\
\hline 7 & +1 & +5 & 4 & 11.5 & 18 & +5 & +6 & 1 & 2 \\
\hline 8 & -4 & +1 & 5 & 17 & 19 & -1 & +4 & 5 & 17 \\
\hline 9 & -3 & +2 & 5 & 17 & 20 & -4 & 0 & 4 & 11.5 \\
\hline 10 & +2 & +3 & 1 & 2 & 21 & -2 & +3 & 5 & 17 \\
\hline 11 & +2 & +5 & 3 & 8.5 & & & & & \\
\hline
\end{tabular}


signed-rank test because the difference between their pre- and post-test scores was 0 . Since all of the scores were in the same direction, i.e., positive, it was unnecessary to perform further statistical computations. Using the Wilcoxon matched-pairs signed-rank test it was determined the value of $T$ is 0 , and it is estimated $P$ would be significant at both the .01 and .005 levels on both a one- and two-tailed test. Hence, the null hypothesis is rejected. This indicates the classroom teacher noted a significant change in the children's listening skills and ability to express themselves clearly and willingly in a majority of cases following the eight-week program.

The classroom teacher completed a supplemental rating form directed to the teachers' judgment of the children's improvement in speech, language, and listening skills as a result of the program. The purpose of this rating was to determine the amount of growth in the areas enumerated above during the eight-week period. In addition, the teacher made a judgment on the level of the children's enjoyment of participation in the program. The total possible range of scores on this supplemental three-item measure was -6 to +6 . (Refer to Appendix F.) Table VI reveals the raw data of this supplemental teacher rating. The mean of +4 indicates positive growth in speech, language, and listening because of the program and supports the opinion of a high level of enjoyment on the part of the children. These data were not statistically treated because they did not fit into the pre- and post-test design of the study and they deal solely with the teachers' impressions. 
TABLE VI

RAW DATA FHOM THE SUPPLEMENTAL TEACHER RATING FORM OF SPEECH, IANGUAGE, AND LISTENING SKILIS AND

LEVEL OF ENJOYMENT OF THE PROGRAM

OF 25 KINDERGARTEN CHILDREN

\begin{tabular}{cc|cccc}
\hline \hline Subject & Rating & Subject & Rating & Subject & Rating \\
\hline 1 & +5 & 10 & +4 & 18 & +5 \\
2 & +4 & 11 & +5 & 19 & +5 \\
3 & +5 & 12 & +2 & 20 & +5 \\
4 & +2 & 13 & +4 & 21 & +4 \\
5 & +6 & 14 & +5 & 22 & +5 \\
6 & +4 & 15 & +6 & 23 & +5 \\
7 & +4 & 16 & +4 & 24 & +6 \\
8 & +4 & 17 & +4 & 25 & +4 \\
9 & +4 & & & & \\
\hline
\end{tabular}

\section{DISCUSSION}

The primary purpose of this study was to determine if the teaching of talking and listening to a kindergarten class for an eight-week period would demonstrate gains in articulation, voice, language, and listening skills. A discussion of each of these areas, the teacher rating scale, supplemental teacher rating scale, and the experimental program follows. 
Speech

It was expected there would be an increase in childrens' articulation ability. Gains in articulation were made in the following phonemes which were specifically taught:

$$
/ \mathrm{b} /, / \mathrm{d} / \mathrm{d} / \mathrm{v} / \mathrm{r} / \mathrm{r} / \mathrm{l} / \mathrm{d} / \mathrm{d}_{3} /, / \mathrm{s} /, / \theta /, / \mathrm{s} / \text {, and } / \mathrm{t} S /
$$

It is possible, of course, the kindergarten children in this study could have made the same pre- and post-test gains without speech improvement lessons as a consequence of maturation. There was a significant difference before and after the training period with a t-value of 2.55, $P<.01$, d.f. 48, on a one-tailed test. This finding would tend to be compatible with the reports of Van Riper (1953), Wilson (1954), Jones (1957), Byrne (1960), and Sommers and others (1961). This result also appears to be compatible with that of the Wilson (1954) study dealing with the reduction of the number of articulation errors in a group of kindergarten children. The articulation result of this investigation also is supportive of the Jones (1957) study, which demonstrated significant gains, following training over a period of one school year, in the correct articulation of sounds in the initial and medial positions.

The data collected by this investigator corroborates the Sommers and others (1961) study, which examined the effect of speech improvement on articulation skills of first grade children, and concluded children who received regular speech improvement exhibited greater improvements in articulation skills than children who received no speech improvement. Planned instruction in the improvement of speech, which has a positive relationship to gains in articulation abilities, 
was also one of the conclusions reached in the ASHA report (Garrison et al., 1961).

Voice

The findings in the vocal parameters included in this investigation were not congruent with the observations of such authorities as Van Riper (1953) and Garrison and others (1961) relative to the teaching of vocal skills in the elementary classroom. No statistically significant difference existed between the pre- and post-test measures. The pre-test revealed eighteen scores of normal with twenty-two scores of normal on the post-test. This investigator would hypothesize that voice, unlike articulation, involves the use of more complex vocal skills which rely on more abstract and less precise teaching methodologies. It should be mentioned, however, the parameters of pitch and loudness are more easily demonstrated in a teaching situation than that of rate. Additionally, the experimental management program did not provide as many direct activities for the improvement of vocal skills as it did in the three other areas of speech, language, and listening. This author would tend to believe an extended training period, including direct intervention activities for the vocal parameters mentioned above, might result in more significant gains.

\section{Language}

The pre- and post-test scores of language were not statistically significant at the .05 level. The $\underline{t}$ score of this investigation was 1.33, d.f. 48; and to be significant at the .05 level it would need to be 1.67. This investigator believes that learning to use language, 
like learning to improve and control the several vocal parameters, is a more complex and abstract skill which includes the capacity to listen, to process incoming signals, to remember and relate current experiences with previous experiences, and to express ideas and concepts (Eisenson and Ogilvie, 1971). If this is indeed true, then it would be logical to assume a training period of greater than eight weeks, utilizing activities which provide more practice with language concepts, could possibly demonstrate a more significant gain or improvement in the overall language ability of children. This reasoning is based upon the small differential between the obtained $\underline{t}$ score in the present investigation and the expected score of significance at the .05 level of confidence; however, the factor of maturation, once again, must be kept in mind during such reasoning. The direction of this investigator's reasoning relative to improvement in language abilities tends to be supported by authors whose views are not specifically supported by statistical data but rather clinical experience (Van Riper, 1953; Wilson, 1954; Van Riper and Butler, 1955; English, 1958; Lysaght, 1960; and Garrison et al., 1961). They tend to reflect the view that language teaching, utilizing a planned intensive program which goes beyond the average language arts program, could possibly demonstrate greater improvement in the language skills of kindergarten children.

\section{Listening}

A significant difference was noted in a comparison of pre- and post-program listening scores of the children in this study. These findings appear to be compatible with the writings of Nichols and Lewis 
(1963) in the area of listening. In a discussion of the teaching of listening, they report negative evidence is unavailable on the improvement of listening ability following direct training in listening comprehension, and positive evidence of very impressive proportions is fast accumulating (Nichols and Lewis, 1963). They conclude, from their data, listening can be taught effectively and successfully. The present investigation tends to lend support to this view with a strong statistical difference $(\mathrm{P}<0005)$ between pre- and post-training conditions.

\section{Teacher Rating}

The teacher rating scale which assessed the childrens' listening skills and ability to express ideas clearly and willingly on a pre- and post-program basis was statistically treated with the Wilcoxon matchedpairs signed-rank test which revealed $P$ was significant at both the .01 and the .005 levels on both a one- and two-tailed test. Visual inspection of the raw data demonstrated a strong significant difference in the pre- and post-program teacher rating indicating gains in the children's listening skills and ability to express ideas clearly and willingly. It should be noted the kindergarten teacher in this study was desirous of speech improvement activities and could have been influenced, to some degree, during the rating process.

\section{Supplemental Teacher Rating:}

Although not part of the original design, three questions were presented to the teacher in order to aid in determining the possible amount of improvement made by the children in the areas of listening 
skills, clarity and willingness of expression, and enjoyment of the program during the eight-week period. Once again, these questions required a value judgment on the part of a receptive teacher. The results of this supplemental teacher rating form revealed a mean of +4 , which indicates she noted positive growth in speech, language, and listening because of the program and was of the opinion the children demonstrated a high level of enjoyment in the speech activities.

Because of her daily and varied contact with children, the classroom teacher is experienced and qualified to make judgments concerning expressive ability, willingness to speak, and listening levels. Results of this investigation are supported also by the English (1957) survey of teacher evaluations of speech improvement wherein they expressed unanimous approval of a speech improvement program, and felt children increased in their language skills. Compatible with the current study is the ASHA report (Garrison et al., 1961) which stated teacher ratings are comonly utilized in measuring the effectiveness of speech improvement.

\section{Experimental Program}

The gains demonstrated by the children in this study leads this investigator to believe the Learning Language Skills-I (Scott, 1971) program for teaching speech and language at the preschool level is a useful tool, and might be credited with the significance of some of the findings. 


\section{CHAPTER V}

\section{SUMMARY AND IMPLICATIONS}

\section{SUMMARY}

Previous speech improvement studies have demonstrated significant gains in reading (Jones, 1951; Sommers et al., 1961; Sommers, 1962; and Sawyer, 1965). In addition, speech improvement studies concentrating on articulation ability have established gains (Van Riper, 1953; Wilson, 1954; Jones, 1957; Van Hattum, 1959; Byrne, 1960; Sommers et al., 1961; and Sommers, 1962). Most of these studies in speech improvement have dealt with growth in articulation, auditory discrimination, and reading ability. An apparent need, therefore, existed to investigate not only articulation but also voice, language, and listening at the kindergarten level. Twenty-five subjects were included in this study, which purported to examine and estimate the effectiveness of a group speech and language improvement program on the speech and language skills of children at the kindergarten level.

This investigation was designed to compare pre-program with postprogram scores in the areas of articulation, voice, language, and listening. Furthermore, a teacher rating form was used to evaluate the children's pre- and post-program levels of listening, clarity of expression, and willingness to speak before the group.

The general question was: 
What are the effects of speech improvement and language stimulation on articulation and speaking skills of kindergarten children?

Significant differences occurred in articulation $(\mathrm{P}<01)$ and listening $(\mathrm{P}<0005)$ skills, and this investigator felt some improvement also was obtained in the areas of voice and language. Thus, it might be stated, at this point, there appears to be a strong positive relationship between a carefully planned speech and language improvement program for kindergarten children and their gains in speech and language ability. The progress made by the children in this study leads this investigator to believe the Scott (1971) program for teaching speech and language is a useful tool and might be credited with some of the significant findings mentioned in the study. The results of the present investigation indicate the participating teacher noted significant improvement in the children's ability to express ideas more clearly and willingly and to listen more effectively after a planned speech and language program.

\section{IMPLICATIONS FOR FUTURE TRAINING AND RESEARCH}

\section{Training}

Based on the present study, this investigator believes the following implications for speech and language training in the schools at both preschool and primary levels are valuable and reasonable. Planned speech and language programs at the preschool and primary level should be considered by educators as an integral part of a school curriculum. Eight weeks of such a program appear satisfactory for the improvement of articulation and listening skills, but longer and more intensive 
training would be needed for maximum improvement in language and vocal skills.

With the advent of Public Law 94-142 mandating equal educational opportunities for the handicapped child, children with more involved handicaps will begin to appear in the regular classroom; hence, more efficient methods for instructing children on a group basis in the classroom will need to be developed. This investigator would suggest the implementation of a well planned speech and language program which can be taught on a group basis to children of all abilities. Group instruction in speech and language, which is well planned and taught on a regular basis, can be effective and efficient in training a variety of children at several educational levels within a given classroom.

School districts should develop and coordinate the training of personnel in the initiation of speech and language programs for the purpose of increasing the speech and language skills of all children, inclusive of the child with a handicap. Such coordination should be in the hands of a person who not only has training in speech and language methodology, but also is well acquainted with the development of speech and language skills in children. Additionally, knowledge of developmental reading in children would be a most important support area for such a coordinator.

Irwin (1960) writes schools need a speech education teacher to coordinate speech improvement activities which should be taught by a person with a background in classroom teaching plus training in general speech with knowledge of speech improvement and rehabilitation techniques. The need for speech education teachers is apparent, but until 
that position is created in school districts, speech education for all children is without specific direction. The basic role of the speech clinician is to work with children presenting handicaps in speech and language, but the speech clinician needs to assist in the development of speech improvement and language stimulation programs (Irwin, 1960). School districts should consider joint projects in conjunction with universities for in-service training of teachers and specialized persons who could coordinate these programs.

Research

An implication for future research should be developed to test this researcher's contention that greater improvement in language skill may be obtained through a speech and language program if:

(1) The block of time provided for a speech and language program were extended beyond an eight-week period;

(2) The number of sessions per week were increased, but not to exceed thirty minutes in length because speech improvement lessons are generally not longer than twenty-four minutes in length (Garrison et al., 1961);

(3) A more thorough language test be employed in the pre- and post-testing for the purpose of determining specific areas of need in language concepts which should be taught; and

(4) The number of activities for teaching specific language concepts be increased to improve the probability of greater gains in language skills.

Additionally, this investigator would recommend attempting to control for maturation through the use of experimental and control groups.

Another type of research indicated is an empirical study which should be developed to test this investigator's contention that the 
vocal parameters of rate, loudness, and pitch can be improved through a speech and language program if the amount of time given to activities for the refinement of these skills is increased and a more direct methodology employed.

In addition to a direct approach for training the speaking voice, some consideration should be given to what might be described as speaker reticence on the part of a number of children to speak more effectively. In the latter sense, activities aimed at reducing reticence, not only on the part of the underverbalizer but also to the oververbalizer who may appear to talk a great deal but says very little (Steward, 1968), should be included in the project.

It is this investigator's belief there is evidence to indicate the need for a more definitive study correlating speech and language improvement activities with the reading process. This would be especially true if such a study were to emphasize language concepts in the improvement program, since previous studies dealing with the possible relationship between speech and reading have concentrated solely on speech and auditory skills. 
$\underline{\mathrm{S}} \underline{\mathrm{E}} \underline{\mathrm{L}} \underline{\mathrm{E}} \underline{\mathrm{C}} \underline{\mathrm{T}} \underline{\mathrm{E}} \underline{\mathrm{D}}$

$\underline{B} \underline{I} \underline{B} \underline{\mathrm{L}} \underline{\mathrm{I}} \underline{0} \underline{\mathrm{G}} \underline{\mathrm{R}} \underline{\mathrm{A}} \underline{\mathrm{P}} \underline{\mathrm{H}} \underline{\mathrm{Y}}$ 
SELECTED BIBLIOGRAPHY

AINSWORTH, Stanley, ANDERSON, J., CURTIS, J., JONES, M., McLEAN, J. , VAN HATTUM, R., and BINGHAM, D., The speech clinician's role in the public school. ASHA, 6, 189-191 (1964).

ALLEN, Harold, Face east when facing non-English speakers. On Teaching English to Speakers of 0ther Languages, Series I, National Council of Teachers of English (1964).

AMERICAN SPEECH AND HEARING ASSOCIATION, Public school speech and hearing services. Journal of Speech and Hearing Disorders, Monograph Supplement $8(1 \overline{961)}$.

ANDERSON, Paul S., Language Skills in Elementary Education. New York: Macmillan (1972).

ANDERSON, Virgil, and NEWBY, Hayes, Improving the Child's Speech. New York: 0xford University Press (1973).

BENNETT, Clayton, Communication disorders in the public schools. In Lee Travis (Ed.), Handbook of Speech Pathology and Audiology.

New York: Appleton-Century-Crofts (1971).

BLACK, Martha, Speech Correction in the Schools. Englewood Cliffs: Prentice-Hall (1964).

BYRNE, M. C., Results of a speech improvement program for kindergarten and first grade children. ASHA, 2, 360-361 (1960).

BYRNE, M. C., The Child Speaks: A Speech Improvement Program for Kindergarten and First Grade. New York: Harper and Row (1965).

COLE, Roberta, ERVIN, E., SLADE, D., and SUTTON, M., Language and Speech Improvement for Kindergarten and First Grade. Washington, D.C.: U.S. Dept. of HEW, Dept. of Exceptional Children, National Institute of Education (1975).

EISENSON, Jon, The Psychology of Speech. New York: Appleton-CenturyCrofts (1938).

EISENSON, Jon, and OGILVIE, Mardel, Speech Correction in the Schools. New York: Macmillan Publishing (1971).

ENGLISH, Robert H., A demonstration of speech improvement in the primary grades. Speech presented to NEA Convention, Portland, Oregon (1956). 
ENGLISH, Robert H., Speech therapy and speech improvement. Western Speech, 21, 211-215 (1957).

ENGLISH, Robert H., Poise and good speech: Attributes of a good teacher. Oregon Education, 32, 13-15 (1958).

ENGLISH, Robert H., Speech improvement and the speech therapist. Western Speech, 23, 36-41 (1959).

ENGLISH, Robert H., The importance of the classroom teacher in meeting the speech needs of children. The Speech Teacher, 9, 271-275 $(1960)$.

FISHER, Lee, Planning time and facilities. In Rolland Van Hattum (Ed.), Clinical Speech in the Schools. Springfield, Ill.: Charles Thomas (1969).

FREEMAN, Gerald, The speech clinician-As a consultant. In Rolland Van Hattum (Ed.), Clinical Speech in the Schools. Springfield, Ill.: Charles Thomas (1969).

GARRISON, Geraldine, DARLEY, F., AMIDON, H., and BREINHOLT, V., Speech improvement: Public school speech and hearing services. ASHA, Monograph Supplement 8, 78-92 (1961).

HANLEY, Theodore, and THURMAN, Wayne, Developing Vocal Skills. New York: Holt, Rinehart and Winston, Inc. (1970).

HEJNA, R. F., Developmental Articulation Test. In Frederic Darley, Diagnosis and Appraisal of Communication Disorders. Englewood Cliffs: Prentice-Hall (1964).

HUCKLEBERRY, Alan, and STROTHER, Edward, Speech Education for the Elementary Teacher. Boston: Allyn \& Bacon, Inc. (1961).

IRWIN, Futh, The role of the speech therapist in the speech improvement program. The Speech Teacher, 19, 278-282 (1960).

JOHNSON, Wende11, DARLEY, F., and SPRIESTERSBACH, D. C., Diagnostic Methods in Speech Pathology. New York: Harper \& Row (1963).

JONES, Lucy A., A project of speech improvement conducted in two first grades in the Murray schools. Unpublished Master's thesis, University of Utah (1957).

JONES, Morris Va1, The effect of speech training on silent reading achievement. Journal of Speech and Hearing Disorders, 258-263 (1951). 
LOW, Camilla, Selecting and evaluating learning experiences. Guidance in the Curriculum (1955).

LYSAGHT, Carol, An analysis of literature pertaining to speech improvement programs in the public schools. Unpublished Master's thesis, Boston University (1960).

MECHAM, M. J., JEX, J. L., and JONES, J. D., Utah Test of Language Development. Salt Lake City: Communication Research Associates (1967).

MECHAM, Merlin, JONES, J., and JEX, J., Use of the Utah Test of Language Development for screening language disabilities. Journal of Learning Disabilities, 6, 65-68 (1973).

MURPHY, Lois, and LEEPER, Ethel, Language is for Communication: Caring for Children. Washington, D.C.: U.S. Dept. of HEW, Office of Child Development (1974).

NICHOLS, Ralph, and LEWTS, Thomas, Listening and Speaking. Dubuque, Iowa: Wm. C. Brown Company (1963).

OGILVIE, Mardel, Speech in the Elementary School. New York: Ronald (1954).

PENDERGAST, K., Speech improvement and speech therapy in the elementary school. ASHA, 5, 548-549 (1963).

PERKINS, William H., Speech Pathology: An Applied Behavioral Science. St. Louis: C. V. Mosby (1971).

PETRIE, Charles, What is listening? An experimental evaluation of two methods for improving listening comprehension abilities. Doctoral thesis, Purdue University (1961). In S. Duker (Ed.), Listening: Readings. New York: Scarecrow Press (1966).

POWERS, Margaret, What makes an effective public school speech therapist? Journal of Speech and Hearing Disorders, 21, 461-476 (1956).

PRONOVOST, Wilbert, The Teaching of Speaking and Listening in the Elementary School. New York: Longmans, Green, and Co. (1959).

RASMUSSEN, Carrie, Speech Methods in the Elementary School. New York: Ronald Press (1962).

SAWYER, Richard, Better speech for better reading. Elementary School Journal, 7, 359-365 (1965).

SCHUELL, Hildred, Speech development at the intemediate level. The Quarterly Journal of Speech (Apri1 1945). 
SCOTT, Louise Binder, Learning Time with Language Experiences for Young Children. St. Louis: Webster Division, McGraw-Hill (1968).

SCOTT, Louise Binder, Developing Communication Skills: A Guide for the Classroom Teacher. St. Louis: Webster Division, McGraw-Hill (1971).

SCOTT, Louise Binder, Learning Language Skills-I. St. Louis: Webster Division, McGraw-Hill (1971).

SCOTT, Louise, and THOMPSON, J. J., Speech Ways. St. Louis: Webster (1955).

SCOTT, Louise, and THOMPSON, J. J., Talking Time. Navato, California: McGraw-Hi11 (1966).

SHANE, Harold G., REDDIN, Mary, and GILLESPIE, Margaret, Beginning Language Arts with Children. Columbus, Ohio: Charles Merrill Books (1961).

SHINE, R. E., and FREILINGER, J. J., Practical Methods of Speech Correction for the Classroom Teacher. Davenport, Iowa: Gordon Printing (1962).

SIEGEL, Sidney, Nonparametric Statistics for the Behavioral Sciences. New York: McGraw-Hill Book Company (1956).

SOMMERS, Ronald, Effects of various deviations of speech improvement upon articulation and reading. Journal of Speech and Hearing Disorders, 27, 54-61 (1962).

SOMMERS, Ronald, COCKERILLE, C. E., PAUL, C. D., BOWSER, D. C. , FICHTER, G. R., FENTON, A. K., and COPETAS, F. G., Effects of speech therapy and speech improvement upon articulation and reading. Journal of Speech and Hearing Disorders, 26, 27-37 (1961).

STEWARD, Larry A., Attitudes toward communication: The content analys is of interviews with eight reticent and eight non-reticent college students. Unpublished Doctoral thesis, Pennsylvania State University $(1968)$.

VAN HATTUM, Rolland, Evaluating elementary school speech therapy. Exceptional Children, 25, 411-414 (1959).

VAN HATTUM, Rolland, Ed., Clinical Speech in the Schools. Springfield, I11.: Charles Thomas (1969).

VAN RIPER, Charles, The revision of public school speech correction. Unpublished mimeographed material, Western Michigan College (1953). 
VAN RIPER, Charles, and BUTLER, Katharine, Speech in the Elementary Classroom. New York: Harper \& Brothers (1955).

VIORST, Judith, I'll Fix Anthony. New York: Harper \& Row (1969).

WERNER, Lorna S., Speech in the Elementary School. New York: RowPeterson (1947).

WILSON, B. A., The development and evaluation of a speech improvement program for kindergarten children. Journal of Speech and Hearing Disorders, 19, 4-13 (1954). 


\section{$\underline{A} \underline{P} \underline{P} \underline{E} \underline{N} \underline{D} \underline{I} \underline{\mathrm{C}} \underline{\mathrm{E}}$}


APPENDIX A

DEYELOPMENTAL ARTICULATION TEST-.-SCORING BLANK

Name.

Age

Grade

school

Date

(Score as per the lollowing examples. Substitution: b/P; Omisaion: - /p; Distortion: Dist/p.

- Nole: Except where otherwise noted. Developmentsl dge Level gignifies the chronological age by which approximately $90 \%$ or more children are using the sound correctly.

\begin{tabular}{|c|c|c|c|c|c|c|c|c|}
\hline Card & $\begin{array}{l}\text { Dev. Age } \\
\text { Level }\end{array}$ & $\begin{array}{l}\text { Sound } \\
\text { Tested }\end{array}$ & Check words & 1 & 2 & 3 & 160. & Comment: \\
\hline 1 & 3 & $m$ & monkey, hammer, broom & & & & & \\
\hline 2 & 3 & $\mathbf{n}$ & nails, penny, lion & & & & & \\
\hline 3 & 3 & $\mathbf{p}$ & pig. puppy, cup & & & & & \\
\hline 4 & 3 & $\boldsymbol{h}$ & house, dog house, .... & & & & & \\
\hline $\mathbf{s}$ & 3 & $w$ & window, spider-web, $\ldots$ & & & & & \\
\hline 6 & 4 & $\mathbf{b}$ & boat, baby. (bib: $75 \%$ ) & & & & & \\
\hline$?$ & & $-k$ & cat, ehickeat, took & & & & & \\
\hline 8 & 4 & 8 & girl, wagon, (pig: $75 \%)$ & & & & & \\
\hline 9 & 4 & $\stackrel{1}{\longrightarrow}$ & Cork, telephone, taife & & & & & \\
\hline 10 & 5 & $y$ & yellow, onion, (thank-you; Alt.)... & & & & & \\
\hline$\|$ & 5 & ng & -.... fingers, ring & & & & & \\
\hline 12 & 5 & d & dog. ladder, bed & & & & & \\
\hline 13 & 6 & 1 & Iamp, balloon, ball & & & & $\therefore$ & \\
\hline 14 & 6 & $\boldsymbol{r}$ & rabbit, barn, car & & & & & \\
\hline 15 & 6 & $t$ & table, potatoes, cost & & & & & \\
\hline 16 & -6 & sh & shoe, dishes, fish & & & & & \\
\hline $\begin{array}{ll}17 \\
\therefore\end{array}$ & 6 & ch & chair, matches, watch & & & & & \\
\hline 10 & 6 & Blends & drum, clock, blocks, glasnes, srayona & & & & & \\
\hline 19 & 7 & $\mathbf{v}$ & vacuum, television, store & & & & & \\
\hline 20 & 7 & th & thumb, toothbrush, teeth & & & & & \\
\hline 21 & 7 & j & jump-rope. orange-juice, orange & & & & & \\
\hline 22 & 7 & 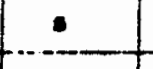 & sun, pencil. bus & & & & & . \\
\hline 23 & ${ }^{?}$ & $\mathbf{x}$ & zebra, scissors. (rubbers: $75 \%$ ) & & & & & \\
\hline 24 & 7 & siends & train, star, slide, swing, spoon & & & & & \\
\hline 25 & 8 & का & this or that, feathers, ... & & & & & \\
\hline 26 & 8 & S!cmatu & occoler, enowran, denk, mat. & & & & & \\
\hline
\end{tabular}


APPENDIX B

ANALYSIS SHEET

Name

1. Of the fifty-four screening test items how many did the subject produce correctly?

2. List all error sounds, indicating position of error. Initial Medial $\underline{\text { Final }}$

3. List all error sounds, indicating type of error. Omission Substitution Distortion 
APPENDIX C

\section{UTAH TEST OF LANGUAGE DEVELOPMENT}

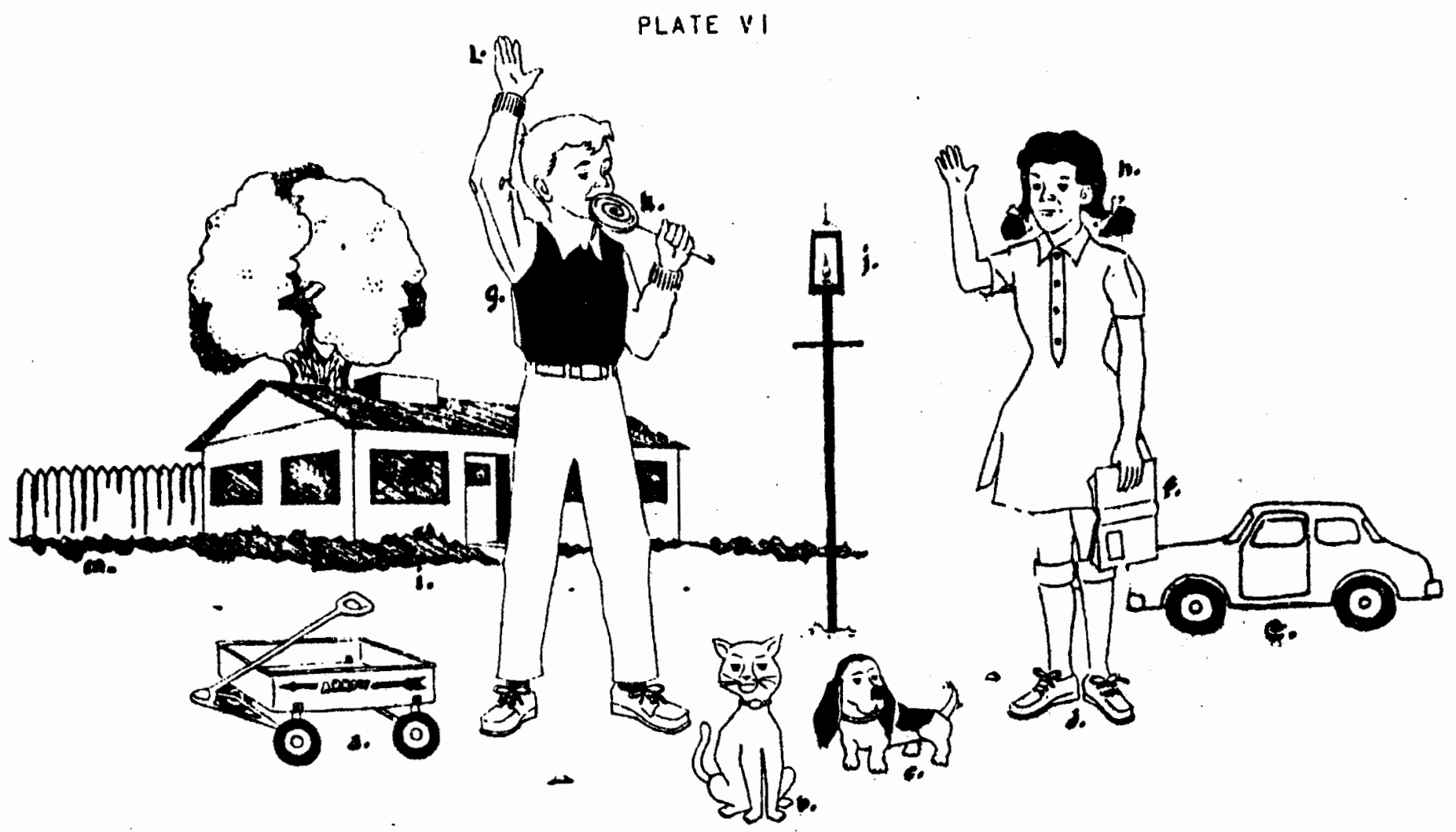

(Mecham et a1., 1967) 


\section{APPENDIX D}

\section{ANALYTIC SPEECH PROFILE}

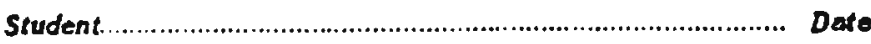

\section{FAuLtS \\ NORHAL}

Time:

Too fast

Too slow

Mionotonous

Uncontrolled variability

Pattemed

Hesitancies

Repetitions

Loudness:

Too loud

Too weak

Monotonous

Uncontrolled variability

Pattemed

\section{Pilch:}

Too high

To low

Monotonous

Uncontrolled variability

Pattemed

Voice Quality:

Nasal

llarsh

Strident

Hoarse

Breathy

Thin

Articulation:

Additions

Omissions

Substitutions

Distortions

General inaccuracy

Oral inactivity

Ovesly precise

$\begin{array}{lllllll}\square & ? & 3 & 4 & 5 & 6 & ?\end{array}$

POSITIVE ATTRIBUTES

Timo:

Over-all rate

Duration of tones

Phrasing

Variation in syllable duraticn

Vatiation in pause curation

Veriation in rate of phrases

Loudness:

Over-all level

Syllable stress

Variation In phrase loudness

Pitch:

Hear optimum ievel

Range

Upwatd inflections

Downward inflections

Pitch skips

Voice Quality:

Describe:

\section{OVER-ALL EFFECTIVENESS}

Note here any deviant sounds and/or deviant speech attributas not listed sbove.
Note here any positive vocel characteristics not llated ebove. 


\section{APPENDIX E}

\section{TEACHER RATING FORM}

Name

In your opinion:

1. Does the child express himself/ herself clearly?

2. Does the child speak willingly before the group?

3. Does the child demonstrate adequate listening skills?
Date

Rating Scale



$\widetilde{-}$

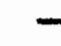

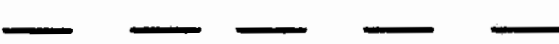


APPENDIX F

TEACHER RATING FORM

Name

In your opinion:

1. Does the child express himself/ herself clearly?

2. Does the child speak willingly before the group?

3. Does the child demonstrate adequate listening skills?

4. To what degree has the child improved his speech and language skills as a result of the program?

5. To what degree has the child demonstrated improved 1 istening skills?

6. To what degree has the child enjoyed the program?
Date

Rating Scale

\begin{tabular}{lcc}
\multicolumn{4}{c}{ Average } \\
-2 & -1 & 0
\end{tabular}$+1+2$

$\longrightarrow$
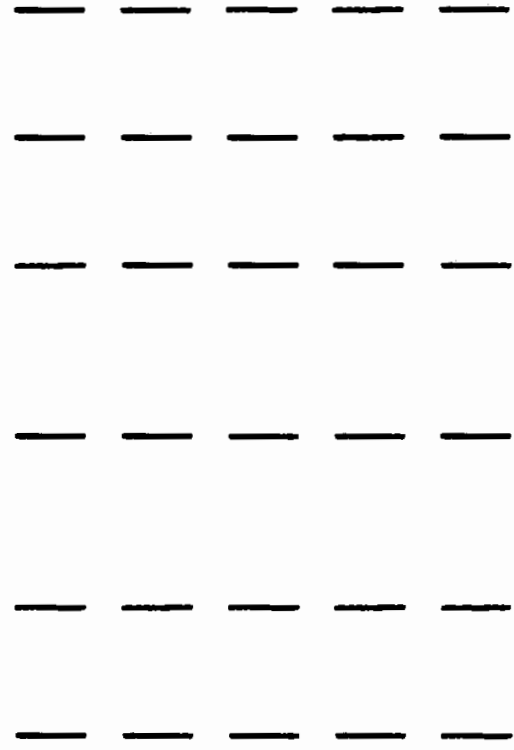


\section{APPENDIX G \\ PERMISSION REQUEST}

\section{Dear Parent:}

I am a graduate student at Portland State University studying how effective a program of speech and language improvement is for the speaking and listening skills of kindergarten children. The program will offer planned exercises in speaking and listening. I have the approval of the Portland Public Schools to conduct this program and, with your permission, I would like to talk with your child and ask him or her some questions.

In no way will your child's name be used in this study. Will you please help me by signing this slip and sending it to school with your child?

Parent's Signature

Thank you,

Marilyn Knauf

Graduate Student-PSU 
APPENDIX H

SAMPLE LESSON PLAN

The $\underline{m}$ sound

"LLS Story Card" pictures, card 1

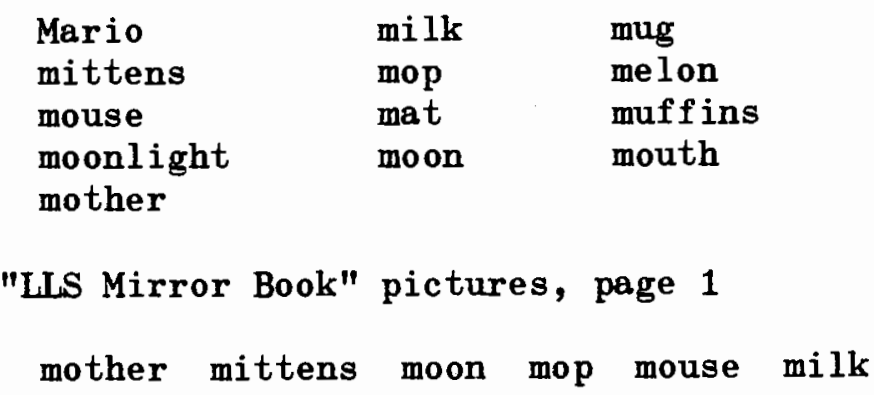

PROCEDURES

1. "LLS Story Card." Children tell what they see in the story illustration. Encourage free conversation. At this time, refrain from discussing the $m$ sound. "Honey Bear" may listen to or say the pictures for the children to repeat.

2. Tell the story on the back of "LLS Story Card."

3. "LLS Mirror Book," page 1. Point to each picture. Ask: What do you see? Watch my mouth as I name the pictures. What did my mouth do? Name the picture with me and feel what your mouth does. Each picture begins with a huming sound. Did you hear that sound as you said each picture?

4. "LLS Mirror Book." Name all the pictures on page 1 and ask children to listen for the humming sound.

5. "LLS Story Card." Ask children to identify objects that begin with the humming sound. (At this point do not use the alphabet name $m$ unless a child mentions it.) Then they identify the objects that do not begin with the humming sound.

6. "LLS Mirror Book." Comprehension and relevancy. Ask: Which ones have feet and mouths? Which one can you drink? Which one makes light at night? Which one is used to clean the floor? Which one is worn on the hands? Which one has a long tail? Which ones talk? Which 
ones do you have at home? Where have you seen the ones you do not have at home? Reasoning. (As children compare items they should think of sizes of real objects and not sizes of illustrated pictures.) Ask: Which is bigger, a moon or a mop? a mitten or a moon? a mother or a mop? Which is longer, a mop or a carton of milk? a mouse's tail or his whiskers? Why would you use a mop? What things could be accidentally spilled?

7. "Small Picture Cards," $\mathrm{m}$. Children identify and match these small pictures with those on page 1 of "LLS Mirror Book." Ask them to compare the small pictures with similar items on "LLS Story Card" 1. Ask: How are they alike? How are they different?

\section{ENRICHMENT}

1. Encourage sentence responses. Show a mitten. Ask: What is this? (Put mitten on child's hand.) What is child's name doing with the mitten? What shall I do with it? This activity helps children become aware and use present, past, and future verb tenses. If a child's answer is only a phrase, "Honey Bear" may praise the child and make a sentence that includes his response for the class to repeat. If a child responds with a verb form that is gramnatically incorrect (i.e., "It be a mitten."), praise him for making a sentence and say his response using the correct verb form for the class to repeat.

2. Sensory perceptions and experiences. Use three empty milk cartons and water to demonstrate and discuss these concepts: full, empty, and half full. Children may pretend the water is milk and take turns holding each carton and describing with these concepts. Ask individuals to feel a pair of mittens and discuss their texture.

3. Show "LLS Story Card." Ask individuals to tell what they do in the morning to get ready for school.

4. Ask "Honey Bear" to say the poem in "Mario goes to School" as children pantomime the actions.

5. Play "The Hummingbird" recording and show accompanying filmstrip for the m sound.

6. Read: Ref. 1. The Monkey Game, p. 353, 2. Off to School, 3. Wake Up Story, 4. Five Little Mice, 5. Hickory Dickory Dock, 6. In the Mirror, p. 6, 7. Read: Frederick. 


\section{A CHAIK TALK}

1. Draw an egg shape.

2. A triangle, too.

3. Now an ear-

Do you have a clue?

4,5. An eye, a tail,

6,7. Whiskers, and feet. And now my mousie

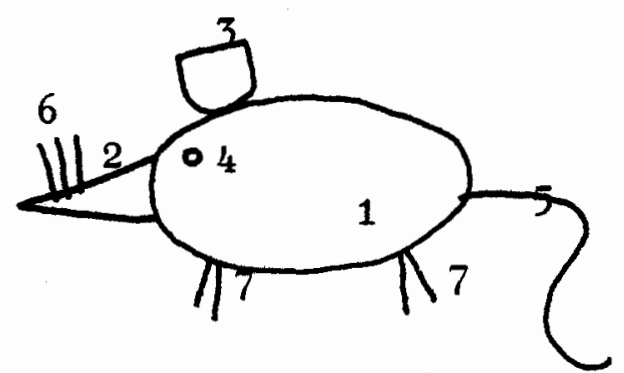
Is complete

(Scott, 1971) 